\title{
El Estado colombiano ante un arbitraje internacional de inversión **
}

\section{Colombia before an international investment arbitration}

SUMARIO

Introducción 1. Algunas nociones sobre los acuerdos internacionales de inversión. 2. El impacto del arbitraje inversionista-Estado en Latinoamérica. 3. Colombia frente al arbitraje inversionista-Estado. 3.1. Reglamentación para la solución de controversias inversionista-Estado. 3.2. Procedimiento de solución de controversias internacionales de inversión. 4. Aspectos relevantes en los arbitrajes inversionista-Estado. 4.1. Algunas cuestiones procesales. 4.2. Cuestiones jurisdiccionales de los tribunales arbitrales. 4.3. Estándares de protección a la inversión extranjera. 5. Casos de arbitraje inversionistaEstado contra Colombia. 5.1. Glencore International A.G. and C.I. Prodeco S.A.v. República de Colombia. 5.2. Eco Oro Minerals Corp.v. República de Colombia. 5.3. América Móvil S.A.B. de C.V.v. República de Colombia.5.4. Cosigo Resources, Ltd., Cosigo Resources Sucursal Colombia, Tobie Mining and Energy, Inc. v. República de Colombia. Conclusiones. Referencias.

\section{RESUMEN}

Los "acuerdos internacionales de inversión" otorgan una serie de garantías y derechos a la inversión extranjera establecida en los Estados receptores; la protección de estos derechos está dada por los mecanismos de solución de controversias inversionista-Estado. Hasta ahora, Colombia está enfrentando por primera vez el reto de defenderse ante un panel arbitral internacional. Para tal propósito, el Estado colombiano ajustó su esquema institucional e implementó mecanismos para prevenir y atender efectivamente las controver-

\footnotetext{
*Abogada de la Universidad Externado de Colombia (Bogotá, Colombia). LL.M. (Master of Laws) in International Commercial Law en Griffith College Dublin. Abogada con experiencia en derecho comercial, administrativo y arbitraje nacional. Contacto: nataliacstrop@gmail.com

${ }^{* *}$ Recibido el 29 de junio de 2016, aprobado el 1. ${ }^{\circ}$ de marzo de 2017.

Para citar el artículo: CASTRO PeÑa, M. N. El Estado colombiano ante un arbitraje internacional de inversión. Derecho del Estado n. ${ }^{\circ}$ 38, Universidad Externado de Colombia, enero-junio de 2017, pp. 23-66. Dor: https://doi.org/10.18601/01229893.n38.02
} 
sias surgidas de estos tratados internacionales, a través de un marco jurídico por etapas, el cual está comprendido por una fase de arreglo directo y una de arbitraje. En línea con lo anterior, se adoptó una política para capacitar sobre los tratados internacionales y comprender su alcance, identificar los riesgos, prevenir las controversias y reducir el riesgo de demandas por las actuaciones de cualquier órgano del Estado.

PALABRAS CLAVE

Acuerdos internacionales de inversión, inversión extranjera directa, solución de controversias inversionista-Estado, estándares de protección.

\section{ABSTRACT}

International Investment Agreements provide guarantees and rights to the foreign investment in the receiving States, the protection of these rights is given by investor-state dispute settlement mechanisms. Thus far, Colombia is facing for the first time the challenge of defending itself before an international arbitration panel. For this purpose, the Colombian State adjusted its institutional scheme and implemented mechanisms to effectively prevent and address the disputes arising from these international treaties, through a stages' legal framework, which is comprised of a negotiation and arbitration phase. In accordance with the above, a policy was adopted in order to train and understand the scope of these international treaties, identify the risks, prevent investment disputes and reduce the risk of claims from the measures taken by any State agency.

KEYWORDS

International investment agreements, foreign direct investment, investor-State dispute settlement, standards of protection.

\section{INTRODUCCIÓN}

Los acuerdos internacionales de inversión tienen como objetivo impulsar la inversión extranjera directa entre los Estados. Esta inversión no puede quedar descubierta ante las transformaciones políticas de los Estados, ante eventuales regulaciones, medidas gubernamentales, estados de emergencia o necesidad, o ante cualquier otra actuación que desmejore las condiciones de la misma. Así, además de las protecciones sustanciales que recogen estos instrumentos internacionales frente a las acciones y omisiones de los Estados y de sus entidades públicas, estos estándares solo son efectivos en la medida en que existen mecanismos a través de los cuales se garantiza su implemen- 
tación, y esto es por medio de las disposiciones de resolución de conflictos inversionista-Estado. La celebración de acuerdos internacionales en Colombia fue tardía; aun así, le posibilitó acoger las posturas de los tratados modernos, que se ven reflejados en los últimos tratados internacionales suscritos.

Ante el abundante número de casos de arbitraje internacional de inversiones, especialmente contra Latinoamérica, y frente a la posibilidad de enfrentar un arbitraje internacional de inversión, se diseñó una política para la prevención y atención de controversias internacionales de inversión. No obstante, la reglamentación, procedimiento e institucionalización con las agencias públicas del Estado fue retrasada, si se observan las fechas de negociación de los primeros tratados. En cualquier caso, se implementó un procedimiento adecuado y se crearon organismos responsables de direccionar las reclamaciones de inversionistas extranjeros para la pronta y oportuna atención, quienes son encargados también de la posterior defensa del Estado colombiano en un eventual arbitraje internacional.

Hasta hace poco, el Estado colombiano era hermético a los paneles arbitrales en el ámbito internacional; el año pasado recibió la notificación de cuatros avisos de arbitraje internacional, tres conforme con las normas del Convenio CIADI y su reglamento, y el restante bajo las reglas CNUDMI. Los casos que enfrenta hoy Colombia tienen que ver con decisiones de la Corte Constitucional que protegen el interés público, como el medio ambiente y el patrimonio público, sanciones impuestas por un ente de control, cambios legislativos, y medidas estatales que afectan los contratos de concesión de los inversionistas extranjeros. El análisis de los casos se presenta observando la experiencia de otros países en hipótesis similares, frente a la protección que se le ha otorgado a la inversión extranjera conforme a los estándares internacionales.

\section{ALGUNAS NOCIONES SOBRE LOS ACUERDOS INTERNACIONALES DE INVERSIÓN}

Los "acuerdos internacionales de inversión" (AII) son tratados internacionales celebrados entre los Estados con el objetivo de atraer inversión extranjera directa (IED) hacia sus territorios, por medio de la creación de condiciones favorables que promuevan y protejan la inversión extranjera en los Estados receptores. A partir de estos tratados se crea un marco jurídico para la IED creando un ambiente de protección, transparencia, seguridad y previsibilidad para los inversionistas extranjeros.

Al hablar de $\mathrm{AII}^{1}$ se debe entender que este término engloba un numero de instrumentos como son: los capítulos de inversión de los tratados de libre

1 Actualmente Colombia tiene 14 AII vigentes: 7 tratados bilaterales de inversión (Perú, España, Suiza, Reino Unido, Japón, China e India) y 7 capítulos de inversión dentro de los trata- 
comercio (TLC), los tratados bilaterales de inversión (TBI), los acuerdos de cooperación económica e, indirectamente, los tratados para evitar la doble tributación que buscan fomentar la inversión en los países. Siendo los dos primeros los convenios más importantes para lograr la promoción y protección de la inversión extranjera en el derecho internacional.

Los TBI tienen un alcance más limitado en comparación con los capítulos de inversión de los TLC, pues la protección a los inversionistas únicamente se extiende una vez la inversión se establece en el territorio del Estado receptor. Por el contrario, los capítulos de inversión de los TLC tienen un mayor nivel de amparo al permitir que ciertas garantías y derechos sean efectivos antes de constituir la inversión en el Estado receptor. Estas prerrogativas se materializan, por ejemplo, al incluir compromisos no discriminatorios o relacionados con el acceso a la economía de cada nación, lo que permite que sean más explícitas las restricciones que el Estado se reserva²

Las disposiciones que regulan la inversión a través de los instrumentos anteriormente descritos abordan, entre otros temas, el comercio de bienes y servicios, derechos de propiedad intelectual, medio ambiente, derechos laborales, contratación pública, acceso a mercados, normas de origen y políticas de competencia ${ }^{3}$. La tendencia reciente es ampliar el espectro de estos tratados, sin embargo hay países que tienen como política reducir la cobertura de los mismos.

Se sobreentiende que uno de los principales propósitos de los AII es reducir los obstáculos a la inversión y garantizar ciertos estándares mínimos de protección a los inversionistas, para evitar la disminución de garantías,

dos de libre comercio (Estados Unidos, Canadá, México, Triángulo Norte, Chile, Corea y Costa Rica). Todos estos tratados internacionales contemplan mecanismos de solución de controversias inversionista-Estado.

2 La manera en que el Estado receptor de la inversión puede mantener restricciones a los compromisos de no-discriminación es mediante las denominadas "reservas a los tratados", donde se consignan aquellas normas o áreas de la economía que el Estado determina sensibles y por lo tanto se reserva la posibilidad de discriminar. Estas reservas a los compromisos de acceso pueden darse de dos formas: por medio de listas positivas, en las que el Estado incluye las áreas de la economía nacional que serán objeto de liberalización, entendiéndose que aquellas donde no hay compromisos se mantienen cerradas a la inversión; y por medio de listas negativas, donde se consignan únicamente las áreas que el Estado se reserva, de manera que lo que no se incluye en esta lista se considera liberalizado. Colombia ha empleado ambos tipos de listados; sin embargo, en virtud de la política de apertura de mercados, hay una marcada preferencia por emplear los listados negativos, los cuales, bajo el criterio de liberalización, proveen mayor transparencia a las restricciones existentes y un mayor acceso para la industria colombiana en los demás países. Departamento Nacional de Planeación. Documento CONPEs 3684 de 2010: Fortalecimiento de la estrategia del Estado para la prevención y atención de controversias internacionales de inversión; disponible en: https://colaboracion.dnp.gov.co/CDT/Conpes/Econ\%C3\%B3micos/3816.pdf [Consultado el 17 de febrero de 2017].

3 United Nations Conference on Trade and Development [UNCTAD] (2008). Regulación internacional de la inversión: balance, retos y camino a seguir. Nueva York y Ginebra: Naciones Unidas. 
imposición de restricciones, tratamiento discriminatorios o arbitrarios. Para tal fin, se incluyen una serie de principios reconocidos por el derecho internacional, como son: el trato justo y equitativo, la nación más favorecida y tratamiento nacional; a los cuales se hará referencia más adelante. Así mismo, se protege la inversión extranjera a través de compensaciones por expropiación directa o indirecta, plena protección y seguridad, y facilidad en las transferencias al exterior ${ }^{4}$.

La negociación de estos AII en Colombia fue tardía en comparación con los demás países de Latinoamérica. La apertura económica colombiana se dio en 1990, a la vez que se suscribieron los primeros AII. Antes de los años noventa, el sector petrolero y minero era el único receptor de inversión extranjera directa, pero con la Constitución Política de 1991 se implementó una política de promoción para la inversión extranjera, cuyo fin era abrir esa brecha a otros mercados y servicios. Así, la IED se albergó principalmente en el sector de petróleo y minería, servicios financieros, manufacturas, electricidad, servicios públicos de gas y agua, la cual estuvo enmarcada por una política de privatizaciones y flexibilización del mercado laboral, entre otras reformas estructurales ${ }^{5}$.

El retraso en la suscripción de AII en comparación con los demás países de la región es uno de los motivos que permite comprender por qué hasta ahora se están presentando los primeros arbitrajes inversionista-Estado contra Colombia.

Estos tratados internacionales otorgan un amparo a la IED frente a las acciones y omisiones de los Estados y de sus entidades públicas, mediante el sistema de resolución de controversias. Por medio de este mecanismo los particulares son categorizados como sujetos de derecho público internacional, debido a que facultan a los inversionistas extranjeros para acceder a la jurisdicción arbitral cuando consideren que las garantías contenidas en los instrumentos internacionales y en el derecho internacional consuetudinario han sido violadas por el Estado receptor.

Antes de utilizar el mecanismo de arbitraje internacional existe un periodo de arreglo directo para que el Estado receptor llegue a un acuerdo con el inversionista. Algunos tratados permiten que el inversionista someta la controversia a la jurisdicción del país donde se realizó la inversión, como una

4 Actualmente, la Conferencia de las Naciones Unidas sobre Comercio y Desarrollo (UNCTAD) está trabajando en una reforma sistemática para cambiar el régimen actual aplicable a los AII, el cual tiene como objeto formular una nueva generación de políticas de inversión, encaminadas a movilizar el flujo de inversión, maximizar el desarrollo sostenible y minimizar los riesgos sin que estos impacten en la formulación de nuevas políticas públicas por parte de los Estados.

5 Garavito, A.; Iregui, A. y Ramírez, M. Inversión extranjera directa en Colombia: evolución reciente y marco normativo. Borradores de Economía, Banco de la República, n. ${ }^{\circ}$ $713,2012,1-64$. 
alternativa al arbitraje internacional ${ }^{6}$, y algunos otros exigen el agotamiento de procedimientos administrativos locales antes de proceder con un arbitraje inversionista-Estado.

Ahora bien, este arbitraje internacional ha sido criticado a nivel mundial, especialmente por los países latinoamericanos, por la afectación a la soberanía nacional de los Estados y su impedimento de regular con libertad, sin que ello implique una compensación por la afectación al valor económico de la inversión extranjera.

\section{EL IMPACTO DEL ARBITRAJE INVERSIONISTA-ESTADO \\ EN LATINOAMÉRICA}

Durante las últimas décadas se ha observado que la mayoría de reclamaciones han sido en contra de los países de América Latina; a pesar de ello, el número de arbitrajes en contra de estos países ha disminuido notablemente en los últimos años?

El exorbitante número de casos arbitrales en contra de la región sugirió una disminución de inversión extranjera en algunos países, y ha llevado a que los Estados reduzcan el número de tratados internacionales celebrados. Por otra parte, el efecto negativo de los arbitrajes inversionista-Estado ha dado lugar al resurgimiento de la doctrina $\mathrm{Calvo}^{8}$, según la cual las disputas de inversión extranjera deben ser conocidas en la jurisdicción del Estado receptor. Como consecuencia de ello, países como Venezuela, Bolivia y Ecuador denunciaron el Convenio del Centro Internacional de Arreglo de Diferencias relativas a Inversiones (CIADI).

Una de las críticas que con mayor frecuencia se escucha es que la suscripción de AII no implica una mayor atracción de inversión extranjera; especialmente si se consignan cláusulas de solución de controversias. Estudios de organizaciones internacionales han afirmado que no existe una correlación

6 BlackABy, N. El arbitraje según los tratados bilaterales de inversión y tratados de libre comercio en América Latina. Revista Internacional de arbitraje, Legis, $\mathrm{n} .{ }^{\circ}$ 1, junio-diciembre, 2004, 17-63.

7 Actualmente, según las cifras registradas en el Banco Mundial, los casos registrados en contra de países de América del Sur bajo el Convenio CIADI y el Reglamento del Mecanismo Complementario corresponden al 24\%, y el número de nuevos casos registrado en 2016 en la región fue de 8 casos, incluidos los 3 iniciados contra Colombia. Centro Internacional de Arreglo de Diferencias Relativas a Inversiones [CIADI] Carga de casos del CIADI - Estadísticas (Edición 2017-1); disponible en: https://icsid.worldbank.org/en/Documents/resources/ICSID\%20Web\%20 Stats\%202017-1\%20(Spanish)\%20Final.pdf [Consultado el 19 de febrero de 2017].

8 La doctrina Calvo, denominada así por Carlos Calvo (jurista internacional argentino), tiene tres pilares: i) los contratos con inversionistas extranjeros no deben tener un tratamiento superior al otorgado a los nacionales; ii) exclusividad de la jurisdicción local, y iii) exclusión de la protección diplomática. 
entre el flujo de IED recibida y los tratados internacionales con cláusulas de arbitraje inversionista-Estado 9 .

Un ejemplo de ello es Brasil, quien no ha ratificado ningún твı у a pesar de ello es el país que recibe la mayor inversión extranjera de la región. Países como Brasil, Sudáfrica, Australia e Indonesia han rechazado la inclusión de cláusulas que contengan un mecanismo de solución de conflictos inversionistaEstado en aras de salvaguardar la soberanía nacional. En suma, podría concluirse que en las cláusulas de arbitraje pareciera que la balanza está inclinada a favor de los derechos de los inversionistas extranjeros en detrimento de las políticas nacionales de los Estados receptores, transfiriendo los riesgos a los Estados y a la vez reduciendo el espectro de su política nacional ${ }^{10}$.

Con todo y ello, pareciera ser que los Estados estuvieran en una encrucijada, especialmente los países en desarrollo y subdesarrollados. Por un lado, existen dudas por parte de los Estados sobre si la firma de AII que contienen mecanismos de resolución de conflictos, en los cuales se somete al Estado a equipararse en igualdad de condiciones con un particular en un proceso arbitral, vaya a atraer una mayor IED; adicionalmente, si el laudo es desfavorable a las excepciones del Estado puede influenciar negativamente en su ambiente económico internacional. Pero por otra parte, la no celebración de estos tratados con ese tipo de cláusulas puede implicar una disminución en el flujo de IED, el cual sugiere ser un factor determinante a la hora de concluir tratados a nivel mundial, por lo que, de no hacerse, podría perjudicar a los países en su desarrollo económico.

La conclusión más ajustada a la realidad es la señalada por Susan Franck, quien expresó: "Aunque el arbitraje en los tratados de inversión no puede detonar la inversión extranjera directa, la disponibilidad de este tipo de mecanismo de solución de controversias es uno de los factores determinantes en la toma de decisiones de los inversionistas extranjeros" 11 . La experiencia en Latinoamérica en relación con los arbitrajes de inversión ha supuesto que se examinen las inversiones debido a la posibilidad de que sectores significativos para la economía nacional sean controlados por extranjeros, que podrían utilizar sus inversiones con fines de política exterior.

9 El Banco Mundial hizo un análisis de 20 años de los tratados bilaterales de inversión y encontró que los países que concluyeron estos tratados no eran más propensos a recibir IED adicional que aquellos que no han suscrito estos acuerdos. Peterson, L. Bilateral Investment Treaties and Development Policy Making. International Institute for Sustainable Development; disponible en: https://www.iisd.org/pdf/2004/trade_bits.pdf [Consultado el 19 de febrero de 2017].

10 Mortimore, M. Arbitraje internacional basado en cláusulas de solución de controversias entre los inversionistas y el Estado en acuerdos internacionales de inversión: desafíos para América Latina y el Caribe, CEPAL. Serie Desarrollo Productivo; disponible en: http://repositorio.cepal. org/bitstream/handle/11362/4583/1/S0900332_es.pdf [Consultado el 19 de febrero de 2017].

11 FRANCK, S. Foreign Direct Investment, Investment Treaty Arbitration, and the Rule of Law. McGeorge Global Business and Development Journal. Vol. 19, 2007, 337-373. 
Las conclusiones a las que llegue el Estado colombiano en relación a si son efectivos estos AII para atraer más inversión extranjera al país, a pesar del riesgo de una eventual demanda internacional, dependerá de los resultados de los casos que enfrente Colombia yuxtaponiéndolos a los beneficios de la IED recibida.

\section{COLOMBIA FRENTE AL ARBITRAJE INVERSIONISTA-ESTADO}

Como se señaló anteriormente, debido al proceso tardío de negociación de los AII, la experiencia de Colombia ante los arbitrajes inversionista-Estado es diletante. Teniendo como antecedente la experiencia de los demás países latinoamericanos, y en vista de que el país no estaba preparado para prevenir y resolver eficientemente las controversias que surgiesen con ocasión de los tratados o de los compromisos establecidos en los contratos de inversión, fue necesaria una política de ajuste y fortalecimiento institucional para mejorar la habilidad del Estado para defenderse.

Como política de Estado, en el año 2010 se expidió el Documento CONPES 3684 para el "Fortalecimiento de la estrategia del Estado para la prevención y atención de controversias internacionales de inversión", como marco para robustecer al Estado en su capacidad de defensa para la oportuna prevención y atención de las controversias que surgiesen entre el inversionista extranjero y el Estado colombiano en virtud de los AII. El objetivo de este documento parte del esquema institucional existente para proponer ajustes para la prevención y atención de las eventuales controversias internacionales de inversión.

Este documento integra medidas de prevención en lo que se refiere a la instrucción de los funcionarios públicos acerca del alcance de los AII, la creación de un órgano centralizado para canalizar las comunicaciones entre los inversionistas y el Estado, que a su vez administre las controversias internacionales de inversión, la cual quedó en cabeza de la Dirección de Inversión Extranjera y Servicio (DIES) que lidera todos los asuntos relacionados con las políticas de promoción de la inversión extranjera, la identificación de sus obstáculos, las negociaciones de los AII y, particularmente, actúa como facilitador de acuerdos amistosos en las diferencias sobre AII.

Así mismo, este documento señala la necesidad de expedir un articulado de normas para dotar de herramientas al Ministerio de Comercio, Industria y Turismo (Minciт) para atender las controversias que surjan con inversionistas extranjeros, tanto en la etapa preliminar de arreglo directo como ante un arbitraje internacional de inversión.

Del diagnóstico realizado en el CONPES se identifican varios problemas, entre los cuales se encuentra el desconocimiento de los servidores públicos en todos los niveles de Gobierno, acerca del alcance de los compromisos asumidos en los AII, dejando abierta la posibilidad de quebrantar las obli- 
gaciones asumidas en los mismos, lo que aumentaba la posibilidad de una eventual demanda en un arbitraje internacional ${ }^{12}$.

\subsection{Reglamentación para la solución de controversias inversionista-Estado}

La regulación para la prevención y atención de controversias internacionales de inversión fue tardía si se considera la fecha de que datan los primeros AII y la experiencia de los países vecinos. Solo a partir del artículo 235 de la Ley 1450 de 2011 se consagra el deber de fortalecer la estrategia del Estado para prevenir y atender la defensa en controversias internacionales de inversión de forma óptima, eficiente y oportuna. Para tal propósito se estableció el deber de programar dentro del presupuesto general de la nación aquellos gastos relacionados con las controversias internacionales, y se dispuso que toda información relativa al estudio de una controversia internacional de inversión, el diseño y presentación de la defensa del Estado en la misma tendrá carácter reservado o confidencial (a este punto haremos referencia más adelante).

En virtud de la anterior ley y el documento CONPES de 2010, se expidió el Decreto 1859 de 2012, derogado posteriormente por el Decreto 1939 de 2013, el cual precisa las funciones y el alcance de la Instancia de Alto Nivel de Gobierno (IANG). En concordancia con las anteriores normas se expidió la Resolución 305 de 2014 que reguló el procedimiento para la atención de controversias internacionales de inversión.

El objetivo del Gobierno mediante la creación de estas normas fue crear unas condiciones para obtener una mayor ventaja de los AII y aminorar el riesgo de violar alguna obligación internacional reconocida en cualquiera de estos instrumentos internacionales.

Igualmente, el Gobierno ha estado capacitando por medio de talleres, conferencias y cursos a distintos funcionarios públicos respecto de las obligaciones adquiridas en los AII como política de prevención. Por otra parte, se ha asignado una partida presupuestal para atender los gastos referentes a un arbitraje internacional, como son la consultoría a asesores externos, costos administrativos para la defensa del Estado, y la posible condena en un laudo arbitral. Una reciente directiva presidencial ${ }^{13}$ dirigida a todas las entidades públicas, servidores públicos y particulares que cumplen funciones

12 Departamento Nacional de Planeación. Documento CONPES 3684 de 2010: Fortalecimiento de la estrategia del Estado para la prevención y atención de controversias internacionales de inversión; disponible en: https://colaboracion.dnp.gov.co/CDT/Conpes/Econ\%C3\%B3micos/3816. pdf [Consultado el 17 de febrero de 2017].

13 Presidencia de la República. Directiva presidencial n. ${ }^{\circ} 2$ del 27 de abril de 2016: Atención Controversias Internacionales de Inversión; disponible en: http://es.presidencia.gov. co/normativa/normativa/DIRECTIVA \%2002\%20DEL\%2027\%20DE\%20ABRIL\%20DE\%202016.pdf [Consultado el 19 de febrero de 2017]. 
públicas, instruye la manera en la que debe ser el manejo de la información en el evento de una controversia internacional de inversión, con el fin de tener una preparación adecuada que permita al Estado identificar los riesgos, prevenir las controversias y reducir el riesgo de demandas por las actuaciones de cualquier órgano del Gobierno.

\subsection{Procedimiento de solución de controversias internacionales de inversión}

A continuación se enuncian los principales actores que participan en la oportuna, óptima y eficiente prevención y atención de las controversias inversionista-Estado, de acuerdo con las normas anteriormente señaladas:

i. Instancia de Alto Nivel de Gobierno. Está en cabeza del Consejo Directivo de la Agencia Nacional de Defensa Jurídica de la Nación, órgano encargado de orientar y formular recomendaciones dirigidas al Mincit para la idónea atención de las controversias internacionales de inversión.

Otra función importante establecida en el Decreto 1939 de 2013 es definir los criterios conforme a los cuales se hará efectiva la conciliación o arreglo directo con el inversionista, y hacer las recomendaciones del caso al comité de conciliación respectivo para que se apruebe la conciliación.

ii. Grupo de Apoyo Interinstitucional. Es coordinado por la Dirección de Inversión de Extranjería y Servicios del Mincit, quien tiene como deber plantear las posibles recomendaciones en relación con los asuntos que pueden ser objeto de controversia. Estas recomendaciones son llevadas por la Secretaría Técnica para apoyar a la Instancia de Alto Nivel de Gobierno y al Mincit en la defensa del Estado.

iii. Ministerio de Comercio, Industria y Turismo. Está a cargo de la defensa del Estado en los procedimientos de conciliación y arbitraje de inversión con el apoyo de los dos anteriores actores, y será la única voz frente al inversionista.

El procedimiento de solución de controversias internacionales de inversión en Colombia está conformado por dos etapas:

\begin{tabular}{|l|l|}
\hline \multicolumn{1}{|c|}{$\begin{array}{c}\text { 1. Etapa de consultas y arreglo directo } \\
\text { o amistoso }\end{array}$} & \multicolumn{1}{|c|}{ 2. Etapa de arbitraje } \\
\hline Notificación de una controversia & Notificación de la intención de demandar \\
\hline $\begin{array}{l}\text { Informe y conformación del grupo de apoyo } \\
\text { interinstitucional }\end{array}$ & $\begin{array}{l}\text { Preparación del Estado colombiano para el } \\
\text { arbitraje }\end{array}$ \\
\hline $\begin{array}{l}\text { Acciones para coordinar y orientar la defensa } \\
\text { del Estado en la etapa de arreglo directo o } \\
\text { amistoso }\end{array}$ & Arbitraje internacional \\
\hline
\end{tabular}


- Etapa de consultas y arreglo directo o amistoso

Esta etapa de arreglo directo es conocida como cooling-off period (periodo de enfriamiento), el cual es un periodo (normalmente de seis meses) de consultas y negociaciones entre el inversionista y el Estado receptor antes de que las partes puedan acudir a la etapa arbitral. El propósito de esta etapa es darle la oportunidad al Estado receptor de conocer el objeto de la futura demanda, y solucionar la controversia antes de que sea sometida a un arbitraje internacional. En la práctica esta cláusula ha sido criticada por considerarse como un simple periodo de espera ${ }^{14}$ para poder activar la vía arbitral, el cual solo incrementa los costos y gastos de la controversia.

Frente a este cooling-off period ha habido tres posturas. La primera, que se trata de un requisito jurisdiccional que debe cumplir el demandante antes de activar la vía del arbitraje, de lo contrario se podría alegar la falta de jurisdicción, tal como ocurrió en Murphy Exploration and Production Company International v. República de Ecuador ${ }^{15}$.

La segunda posición considera que se trata de un requisito de procedibilidad, según el cual el incumplimiento de este periodo no impide hacer efectivo el acuerdo arbitral, ni supondría la pérdida de jurisdicción por parte del tribunal arbitral; por el contrario, se suspende el proceso arbitral para dar cumplimiento a este procedimiento, y si el incumplimiento persiste podría dar lugar al rechazo de la demanda. Esta tesis fue adoptada en Ethyl Corporation v. Canadá ${ }^{16}$.

La tercera postura señala que, sin desconocer la importancia de esta etapa previa, si estas consultas y negociaciones entre las partes son imposibles y fútiles, no se puede entorpecer el acceso al procedimiento arbitral; es decir, el cooling-off period está hecho para facilitar un acuerdo amistoso, y su naturaleza no es impedir el procedimiento arbitral. Así lo estimó el tribunal arbitral de BiwaterGauff v. Tanzania ${ }^{17}$.

Según la regulación colombiana, el procedimiento previsto para activar los mecanismos de solución de controversias inversionista-Estado inicia con la notificación escrita de una controversia por parte del inversionista ante la DIES, y si se recibe en una entidad distinta deberá remitirse a esta Dirección en un plazo de cinco días hábiles; la notificación deberá contener los requisitos mínimos exigidos en cada AII. La DIEs podrá solicitar una complementación o

14 Torterola, I. Cláusulas escalonadas en el arbitraje de inversión. En: Soto, C. Tratado de derecho arbitral . Colección Estudios n. ${ }^{\circ}$ 2. Bogotá: Pontificia Universidad Javeriana, Facultad de Ciencias Jurídicas, Grupo Editorial Ibáñez e Instituto Peruano de Arbitraje, 2011, 287-295.

15 Murphy Exploration and Production Company International vs. República del Ecuador, Caso CIADI n. ${ }^{\circ}$ ARB/08/4. Decisión sobre jurisdicción.

16 Ethyl Corporation v. The Government of Canada, Caso unCiTRal (24 de junio de 1998). Decisión sobre jurisdicción.

17 Biwater Gauff (Tanzania) Ltd. v. United Republic of Tanzania, Caso CIADI n. ${ }^{\circ}$ ARB/05/22. 
aclaración, que incluya una descripción de los hechos, del acto u omisión del Estado colombiano que fundamenta el reclamo, y los documentos pertinentes para esclarecer la controversia.

Una vez recibida la notificación, el Mincit emitirá una comunicación acusando recibo de los respectivos documentos e informando el trámite aplicable. Así mismo, dará aviso por escrito a la Secretaría General de la Agencia Nacional de Defensa Jurídica del Estado, o a su designado, quien deberá comunicar esta circunstancia a la Dirección de Defensa Jurídica de la entidad para que determine las gestiones de apoyo a adelantar en la controversia planteada.

Dentro de los diez días siguientes a la notificación de la controversia se deberá determinar si para el caso concreto se han agotado los recursos administrativos internos, y la DIEs examinará si el reclamante ha ejercido algún medio de control o alguna acción judicial en Colombia.

La DIES elaborará un informe para poner en conocimiento a la Instancia de Alto Nivel de Gobierno (IANG) por medio de la Secretaría Técnica, que contendrá: i) la notificación presentada por el reclamante; ii) el AII sobre el que se presenta la notificación; iii) las entidades involucradas; iv) el plazo para llevar a cabo la etapa de consultas o arreglo directo; v) la presunta fecha para la primera reunión con el inversionista. Dentro de dicho informe se solicitará a los miembros de la IANG que dentro de los ocho días siguientes al recibo de la solicitud se designe a los funcionarios que integrarán el Grupo de Apoyo Interinstitucional, y si existe la necesidad de incorporar a este grupo funcionarios de otras entidades estatales.

Dentro de los veinte días hábiles siguientes a la notificación de la controversia se preparará la convocatoria y el orden del día para la reunión de la Alta Instancia del Gobierno que tendrá como finalidad preparar la primera reunión con el inversionista reclamante con miras a propiciar un arreglo directo o acuerdo amistoso.

En las reuniones de la IANG, la entidad con la que se surgió la controversia tendrá derecho a voz, pero no a voto. De igual forma, la Procuraduría General de la Nación podrá ser convocada a estas sesiones, al igual que los funcionarios de las diferentes entidades cuya participación sea estimada oportuna por la Alta Instancia del Gobierno.

En las reuniones de la IANG, la DIES presentará a esta los resultados de las averiguaciones preliminares, el informe técnico emitido por el Grupo de Apoyo Interinstitucional y demás información y documentos que considere pertinentes.

La IANG evaluará el documento emitido por el Grupo de Apoyo Interinstitucional, y recomendará la adopción de medidas o acciones para resolver la controversia internacional de inversión presentada, entre ellas, la aplicación de mecanismos alternativos de solución de controversias, y definirá los lineamientos y criterios a tener en cuenta en las negociaciones que se realicen con 
el reclamante con miras a propiciar un arreglo directo o amistoso, siempre que se salvaguarde el interés nacional. De ser necesario, definirá también las entidades y funcionarios del orden nacional o territorial que deben estar presentes en las reuniones que se celebren con el reclamante.

La DIES fijará fecha y hora para la realización de la primera reunión con el reclamante, a quien se le informará del objetivo de la reunión y sobre las entidades y funcionarios que estarán presentes.

El delegado del Mincit actuará como vocero del Estado colombiano en la reunión con el inversionista reclamante. En esta reunión, el inversionista extranjero podrá exponer los hechos y el fundamento de la reclamación para soportar sus intereses y pretensiones. En la misma se acordarán los términos y condiciones que regirán sus actuaciones durante la etapa de consultas y arreglo directo o amistoso, en la que se podrá establecer un acuerdo sobre el carácter confidencial de las deliberaciones y de la información relevante.

Este aspecto relativo a la confidencialidad solo tiene sentido en la medida en que no se ventile la información a los medios de comunicación o al público en general, para no generar especulaciones o desinformación. Es importante que esta reserva no se restrinja a terceros interesados, e.g., onG, comunidades indígenas, poblaciones minoritarias, etc., que puedan resultar afectados directa o indirectamente por las decisiones que se tomen al interior de estas reuniones. Por un parte, estos terceros podrían presentar fórmulas para salvaguardar el internes público, y a la vez se podría precaver una potencial demanda por parte de estos grupos contra el Estado colombiano en caso de que sean vulnerados sus derechos en los términos en que se concluya la negociación. Vale advertir que en el arbitraje internacional los reglamentos del CIADI y de la Comisión de las Naciones Unidas para el Derecho Mercantil Internacional (CNUDMI) permiten la intervención de amicus curiae ${ }^{18}$ con ciertas restricciones, y lo mismo podría plantearse en esta etapa de arreglo directo. Por ejemplo, permitir que estos terceros interesados asistan a las reuniones del Grupo de Apoyo Interinstitucional.

Finalmente, las posteriores reuniones que se realicen entre el reclamante y el Estado colombiano se desarrollarán de conformidad con las recomendaciones que a este respecto emita la IANG.

En caso de que las partes lleguen a un acuerdo parcial o total sobre los asuntos objeto de la controversia internacional se suscribirá un documento que así lo manifieste, y se aplicará lo dispuesto en el AII respectivo, además de la manifestación expresa del reclamante de renunciar a demandar al Estado

18 Son terceros que aunque no son parte de la disputa internacional tienen un interés en la resolución del litigo. Estos terceros pueden asistir a la totalidad o parte de las audiencias y presentar amicus briefs (aportes jurídicos o técnicos) en los arbitrajes de inversión cuando así lo autoricen las partes. 
colombiano ante cualquier organismo internacional con base en los mismos hechos. Al respecto se pone de presente que en derecho internacional no hay una norma que prohíba al inversionista renunciar a sus derechos, pero si el inversionista quiere reclamarlos, no puede impedírsele acudir ante un juez o un tribunal competente, independiente e imparcial para hacer efectivos los mismos ${ }^{19}$. Esta renuncia siempre debe respetar los límites del derecho y orden público internacionales, y nada impide que en la renuncia se pacte la selección de un foro arbitral alternativo ${ }^{20}$. En Waste Management v. México el tribunal realizó un análisis respecto del efecto jurídico de la renuncia y las formalidades para su validez:

El acto de renuncia, de por sí, es un acto unilateral, ya que su efecto extintivo se ocasiona únicamente por su voluntad. La exigencia de una renuncia en cualquier contexto implica una dejación voluntaria de derechos en cuanto que, en términos generales, este acto produce una sustancial modificación en la situación jurídica preexistente: la pérdida o extinción del derecho. Por lo tanto, renunciar supone el ejercicio de la facultad de disposición de su titular para dar lugar a ese efecto jurídico. En todo caso, cualquier renuncia debe ser clara, explícita y terminante, sin que sea lícito deducirla de expresiones de dudoso significado ${ }^{21}$.

Una vez exista un acuerdo, este será puesto a consideración del comité de conciliación de la entidad cuya acción u omisión generó la controversia internacional de inversión. Respecto de este último punto nada se previó en el evento de que el comité de conciliación decida no aprobar el acuerdo entre el Mincit y el inversionista; si este fuera el caso, ¿dicho acuerdo tendría validez? De tenerlo, ya que se trata de un acuerdo entre el Ministerio y el inversionista, ¿en caso de incumplimiento será el Ministerio quien entre a responder y no la entidad al no ser parte del arreglo que se acuerde?

Por último, señala que para el cumplimiento de las obligaciones de tipo económico provenientes de las obligaciones derivadas de la conciliación las mismas estarán a cargo de la entidad involucrada en la respectiva controversia. Podría haber un problema en la ejecutoriedad de las obligaciones económicas si la entidad no está de acuerdo o si no existe una partida presupuestal para ello, razón por la cual el papel de la entidad deber ser más activo en esta etapa.

En todo momento las partes podrán acordar por escrito extender el periodo de la etapa de consultas y arreglo directo establecido en el AII invocado.

19 Artículo 10 de la Declaración Universal de Derechos Humanos.

20 ANDRADE, X. Renuncia al arbitraje previsto en un tratado: el caso ecuatoriano. Revista ecuatoriana de arbitraje. Instituto Ecuatoriano de Arbitraje. n. . 2, 2010, 183-208.

21 Waste Management, Inc. vs. Estados Unidos Mexicanos, Caso CIADI n. ${ }^{\circ}$ ARB/98/2. Laudo del 2 de junio de 2000, pár. 18. 
Como es obvio, lo ideal ante cualquier controversia internacional de inversión es que se llegue a un arreglo directo con el inversionista extranjero. Aunque es destacable el esfuerzo realizado por el legislador colombiano en la forma como se previó esta etapa de consultas y arreglo directo, podría robustecerse con el ejemplo de Brasil. Como se mencionó anteriormente, este país no ha ratificado ninguno de los TBI suscritos; empero, en su ánimo de promover la inversión extranjera creó su propio modelo, denominado "acuerdos sobre cooperación y facilitación de inversiones" (ACFI), y tiene uno suscrito con Colombia. Estos acuerdos se destacan principalmente por prever únicamente el mecanismo de resolución de controversias Estado-Estado, y no el tradicional arbitraje inversionista-Estado.

Los ACFI tienen comités conjuntos similares a los que tienen los TLC; dentro de las funciones y responsabilidades de estos comités están, entre otras, resolver las cuestiones de manera amistosa y analizar los casos que afecten económicamente la inversión de un inversionista extranjero. La creación de estos comités en los AII suscritos por Colombia o al menos en la regulación que tiene Colombia ayudaría a que esta etapa de arreglo directo sea eficiente a la hora de lograr un arreglo amigable, y a que no se trate meramente de una fase previa que deba agotarse.

Pero la figura más destacable son los "puntos focales nacionales" u "ombudsmen", en donde cada Estado designa a su "ombudsman" para apoyar a los inversionistas extranjeros de la otra parte; están a cargo, entre otras responsabilidades, de gestionar las consultas y reclamaciones del inversionista extranjero del otro Estado con las entidades competentes, y de hacer sugerencias para la solución de controversias, cuando fuere el caso. Asimismo, procuran mitigar los conflictos y facilitan la resolución de controversias con las entidades gubernamentales. El hecho de que estos puntos focales no solo estén conformados por los organismos del Estado receptor sino que en ellos esté representada una entidad del otro Estado parte genera un ambiente de confianza y seguridad para el inversionista en el sentido de que sus reclamaciones van a ser gestionadas en debida forma.

\section{- Etapa de arbitraje}

Fracasadas las negociaciones o el proceso de arreglo directo o amistoso, o efectuados acuerdos parciales entre el Estado colombiano y el reclamante, este último podrá notificar su intención de demandar al Estado colombiano en arbitraje internacional ante la entidad o dependencia que señale el AII; en caso de guardar silencio, esta notificación se presentará ante la Dirección de Inversión Extranjera y Servicios con el cumplimiento de los requisitos especificados en el AII respectivo.

Posteriormente el MinciT comunicará a la Dirección de Defensa Jurídica de la Agencia Nacional de Defensa Jurídica del Estado y a los miembros de la 
IANG el plazo con el cual cuenta el reclamante para presentar la controversia de arbitraje internacional.

Cuando se conozca de la notificación, la gestión del Estado colombiano debe dirigirse a diseñar una estrategia de defensa y prepararse jurídica y técnicamente para el arbitraje internacional.

El Grupo de Apoyo Interinstitucional revisará el estado de la controversia con el objeto de analizar los elementos y componentes que permitan al Estado colombiano prepararse para el arbitraje; en dicho análisis se estudiarán los aspectos que permitirán calificar a la controversia como una controversia cubierta bajo lo previsto en el AII en razón de la persona, de la materia y del tiempo. Así como la presunta violación a las obligaciones contenidas en el AII, las consecuencias económicas de la controversia y elementos que puedan afectar la inversión extranjera en el país. El grupo interinstitucional efectuará las correspondientes recomendaciones del caso.

La IANG en sus reuniones formulará recomendaciones respecto de la adopción de medidas o acciones, lineamientos y estrategias para la defensa del Estado, y la contratación de asesores externos que apoyarán la defensa del Estado en esta etapa de arbitraje internacional.

En esta reunión la Secretaría Técnica presentará a la IANG el informe técnico emitido por el Grupo de Apoyo Interinstitucional y demás información y documentos que considere pertinentes.

Las partes podrán por mutuo acuerdo acudir a una mediación o conciliación, ad hoc o institucional, antes o durante el procedimiento de arbitraje.

Esta reglamentación nada dice respecto de la ejecutoriedad de un laudo arbitral cuando sea desfavorable al Estado colombiano. No obstante, la Convención de Washington ${ }^{22}$ en su artículo 54 establece que los laudos se ejecutarán bajo las normas relativas a la ejecución de sentencias de cada país. Si el arbitraje está regulado por las disposiciones del CNUDMI, el laudo será reconocido y ejecutado de conformidad con la Convención de Nueva York, en el que Colombia también es parte.

La tendencia de otros países en Latinoamérica ha sido desconocer los laudos emanados por estas instancias internacionales y pareciera que el flujo de inversión extranjera directa en estos países no ha disminuido sustancialmente ${ }^{23}$.

Con esta reglamentación el Estado colombiano se fortaleció institucionalmente, para dar cumplimiento a los compromisos pactados en los AII, garantizar la oportuna, óptima y eficiente atención de las controversias

22 Mediante la Ley 267 de 1995 se aprobó el Convenio CIADI.

23 GutiérRez, M. Entre la observancia de los acuerdos de protección a la inversión y el derecho a instrumentar políticas públicas de desarrollo en América Latina. En: ÁlvarEz, J., ed. ¿Hacia dónde va América Latina en el derecho internacional de las inversiones? Bogotá: Universidad Externado de Colombia, 2015, 40. 
inversionista-Estado y crear una estructura para defenderse ante un tribunal de inversión internacional.

\section{ASPECTOS RELEVANTES EN LOS ARBITRAJES INVERSIONISTA-ESTADO}

\subsection{Algunas cuestiones procesales}

La ley aplicable a los arbitrajes de inversión variará si la controversia surge bajo el amparo de las disposiciones de un AII o un contrato de inversión. En el último caso, el derecho aplicable será el que las partes hayan acordado, y a falta de este serán las reglas del centro de arbitraje al cual las partes decidieron someter la controversia ${ }^{24}$.

En relación con los AII se aplicarán las reglas correspondientes al tratado, y cuando este guarde silencio se aplicará las reglas de acuerdo con el centro de arbitraje al que sea sometida la controversia. Si la controversia es sometida a un tribunal arbitral CIADI se aplicará el artículo 42.1 del Convenio de este Centro, el cual reza: "El tribunal decidirá la diferencia de acuerdo con las normas de derecho acordadas por las partes. A falta de acuerdo, el tribunal aplicará la legislación del Estado que sea parte en la diferencia, incluyendo sus normas de derecho internacional privado, y aquellas normas de derecho internacional que pudieren ser aplicables".

Por el contrario, si la controversia se rige por lo dispuesto en las normas de arbitraje de la CNUDMI o de la Cámara de Comercio Internacional (CCI), será el tribunal quien determine la ley apropiada para el caso en concreto ${ }^{25}$.

En los capítulos de protección de inversiones de los TLC y TBI celebrados por Colombia se establece expresamente la ley aplicable a las controversias inversionista-Estado, con excepción del тві Colombia-Reino Unido, que guarda silencio al respecto ${ }^{26}$. En la medida que en los TLC existe una comisión administradora del acuerdo, su interpretación sobre alguna disposición del acuerdo internacional es vinculante para el tribunal arbitral.

24 Endara, F. Derecho aplicable al fondo de la controversia en arbitrajes surgidos de tratados de inversión. Revista Chilena de Ciencia y Política. Vol. 3, n. ${ }^{\circ}$ 1, 2011, 101-117.

25 El artículo 35 del Reglamento de Arbitraje de la Comisión de las Naciones Unidas para el Derecho Mercantil Internacional señala: "El tribunal arbitral aplicará las normas de derecho que las partes hayan indicado como aplicables al fondo del litigio. Si las partes no indican las normas de derecho aplicables, el tribunal arbitral aplicará la ley que estime apropiada". El artículo 21 del Reglamento de Arbitraje de la Cámara de Comercio Internacional dispone: "Las partes podrán acordar libremente las normas jurídicas que el tribunal arbitral deberá aplicar al fondo de la controversia. A falta de acuerdo de las partes, el tribunal arbitral aplicará las normas jurídicas que considere apropiadas".

26 CÁrdenAs, A. Algunas reflexiones sobre la ley aplicable a los arbitrajes de inversión derivados de Acuerdos Internacionales de Inversión; disponible en: http://dernegocios.uexternado. edu.co/D3rn3goc10seuc/wp-content/uploads/2016/11/2016-11-24-Ley-aplicable-en-los-AII.pdf [Consultado el 19 de febrero de 2017]. 
En los AII suscritos por Colombia existen tres tendencias en relación con la ley aplicable a las controversias inversionista-Estado ${ }^{27}$. En la primera, se establece como ley las disposiciones establecidas en el tratado y las reglas aplicables del derecho internacional, sin hacer referencia alguna a la legislación nacional del Estado receptor ${ }^{28}$. Para la segunda, la ley aplicable es la contenida en el tratado internacional, el derecho internacional y la legislación nacional del Estado receptor ${ }^{29}$. Para la tercera, el acuerdo internacional guarda silencio sobre la ley aplicable a las controversias inversionista-Estado, como es el caso del тві Colombia-Reino Unido.

Otras cuestiones procesales principalmente se refieren a las cláusulas tipo "fork on the road", en las que el inversionista debe escoger entre reclamar el objeto de la controversia a través de los mecanismos de arbitraje proveídos en el AII o hacer valer la disputa en los tribunales locales. Existen también aquellas cláusulas de exclusión, que descartan ciertas materias de arbitraje de inversión; por ejemplo, cuando se trate de un asunto de materia tributaria, si las autoridades tributarias de los Estados parte determinan de manera conjunta que no se ha producido una violación, no se puede acudir al mecanismo arbitral. Otra cuestión es la referida a los plazos para activar un arbitraje, en el que el inversionista tiene un plazo $^{30}$ desde que se presentó la controversia para activar los mecanismos de solución de controversias.

De igual forma, el AII puede disponer el agotamiento previo de recursos administrativos locales antes de acudir a un arbitraje de inversión. El procedimiento de estos recursos no podrá exceder de seis meses y no impedirá al inversionista solicitar las consultas y negociaciones referidas en el AII. El agotamiento de este procedimiento administrativo se encuentra comprendido en los тві con Reino Unido, China, España, Japón, Perú y en el capítulo de inversiones del TLC del Triángulo Norte.

\subsection{Cuestiones jurisdiccionales de los tribunales arbitrales}

La jurisdicción de los tribunales arbitrales está condicionada a cuatro criterios ${ }^{31}$ :

27 Ibíd.

28 Ibíd. Por ejemplo en el TBI con Suiza y los capítulos de protección de inversiones de los TLC con México, Colombia, Canadá, Estados Unidos y Chile.

29 Ibíd. Por ejemplo en los твI con España, India y Perú, y el capítulo de protección de inversiones del TLC con el Triángulo Norte.

30 El artículo 10.18 del TLC Colombia-Estados Unidos establece un periodo de tres años para acudir al arbitraje de inversión desde el momento en que el demandante tuvo o debió haber tenido conocimiento de la violación alegada.

31 Según el artículo 25(1) de la Convención CIADI es necesario que existan tres condiciones: ratione personae, ratione voluntatis y ratione materiae. 


\subsubsection{Ratione voluntatis (consentimiento escrito)}

Cuando se está ante un arbitraje con un particular, el Estado plasma su voluntad de someter una controversia a arbitraje mediante un tratado o ley, la cual es considerada como una "oferta" de someter las controversias a arbitraje internacional, que requiere la posterior aprobación por escrito de parte del inversionista $^{32}$. En relación con el consentimiento dado por el Estado, resulta redundante, por cuanto este otorga el mismo cuando suscribe el instrumento internacional ${ }^{33}$.

Por su parte, el consentimiento otorgado por el particular para recurrir a un arbitraje de inversión debe estar conforme con las estipulaciones de cada AII. La aceptación de la oferta por parte del inversionista debe consignarse por medio de un acuerdo escrito, antes de la iniciación del procedimiento arbitral o al tiempo con la interposición de la solicitud de iniciación del procedimiento. No obstante, en la práctica se ha asumido que mediante la solicitud de iniciación de un procedimiento arbitral se entiende otorgado el consentimiento a la jurisdicción del tribunal arbitral ${ }^{34}$; un ejemplo de ello se tiene en American Manufacturing \& Trading, Inc. v. Congo ${ }^{35}$.

\subsubsection{Ratione materiae (inversión)}

La controversia debe versar sobre una inversión bien sea por lo establecido en el AII correspondiente o por lo dispuesto por las partes. Empero, definir qué se entiende como inversión en una controversia internacional, en especial cuando se trata de una mera transacción comercial, no es tan sencillo. Al respecto se han establecido dos teorías: una subjetiva, según el cual la interpretación debe ser siempre la definición de inversión acordada por las partes en el tratado de inversión aplicable; y otra objetiva, que busca definir las características generales de inversión que pueden aplicarse en una variedad de contextos para determinar si un activo particular califica como una inversión ${ }^{36}$.

La "jurisprudencia arbitral" -si se puede llamarla así- ha defendido ambas posiciones. En Fedax v. Venezuela y Salini v. Marruecos se adoptó el criterio objetivo en el que se diferenciaron cinco características típicas de

32 Pérez, Y. Oferta estatal de consentimiento en el procedimiento arbitral CIADI. Ciencias Sociales y Educación, Universidad de Medellín. Vol. 2, n. 3, 2013, 33-64.

33 Heiskanen, V. Ménage à trois? Jurisdiction, Admissibility and Competence in Investment Treaty Arbitration. ICSCID Review, Oxford Academic. Vol. 29, n. ${ }^{\circ}$ 1, 2014, 231-246.

34 Pérez, Y. Consentimiento estatal al arbitraje del CIADI. Lecciones y ensayos. n. ${ }^{\circ}$ 91, 2013, 19-57.

35 American Manufacturing \& Trading, Inc. v. Republic of Zaire, Caso CIADI n. ${ }^{\circ}$ ARB/93/1.

36 HeISKANen, V. Of capital import: The definition of 'investment' in international law. En: Koffmann, A. Protection of Foreign Investments through modern treaty arbitration: Diversity and Harmonisation. ASA Special Series n. ${ }^{\circ}$ 34. Association Suisse de l'Arbitrage Schweiz, 2010, 51-73. 
una inversión, que fueron conocidas posteriormente como el test Salini, a saber: 1) contribución; 2) asunción de riesgo; 3) duración; 4) contribución al desarrollo económico del Estado receptor, y 5) regularidad en la rentabilidad. Algunos tribunales arbitrales han adoptado esta prueba plenamente como requisito jurisdiccional; otros, por el contrario, han tenido un enfoque más flexible y han acogido solo algunos elementos de la prueba, como la duración y la contribución significativa al desarrollo del Estado receptor ${ }^{37}$. En otros tribunales, como en Biwater v. Tanzania y Malaysan Historical Savors v. Malasia, se aplicó el criterio subjetivo, esto es, el de aquello que las partes definieron como inversión.

\subsubsection{Ratione personae (calidades del inversionista)}

El tribunal arbitral solo conocerá de controversias que surjan entre el Estado receptor y un nacional del otro Estado contratante; el concepto de nacional abarca tanto personas naturales como jurídicas. Respecto de las primeras, el artículo 25.2 (a) del Convenio CIADI señala que las personas naturales deben tener la nacionalidad de un Estado contratante distinto del Estado parte de la diferencia, y no tener doble nacionalidad con los Estados contratantes. En relación con las personas jurídicas, se han utilizado dos criterios: el primero es relativo a aquellos tratados que toman como criterio de nacionalidad el lugar de incorporación o asiento principal de los negocios; de acuerdo con el segundo, el tribunal requiere requisitos adicionales para determinar la nacionalidad de la sociedad ${ }^{38}$, como el lugar de constitución de la persona.

En la práctica se presentan algunos inconvenientes a la hora de establecer la nacionalidad de una persona jurídica. Por ejemplo, cuando existe una situación de control, la nacionalidad de los accionistas de la persona jurídica o la sede efectiva de la administración, cuando esta es en un lugar distinto a alguno de los Estados signatarios del tratado.

\subsubsection{Ratione temporis ${ }^{39}$ (entrada en vigor del AII)}

Este criterio hace referencia tanto al ámbito temporal de la entrada en vigor del instrumento internacional como al cumplimiento del plazo establecido

37 Grabowski, A. The definition of investment under the ICsid Convention: A defense of Salini. Chicago Journal of International Law. Vol. 15, n. ${ }^{\circ}$ 1, 2014, 287-309.

38 García, L. y Arévalo, W. Arbitraje de inversión. Definición y aspectos procesales relevantes. En: GARCíA, L.; AluURe, A., eds. Estudios contemporáneos de derecho internacional privado. Bogotá: Universidad del Rosario y Legis Editores, 2016, 243-278.

39 Respecto de este criterio también se ha dicho que la limitación de jurisdicción ratione temporis se exige también para el agotamiento del colling off period y cuando se requiere el agotamiento de recursos administrativos locales. 
en la cláusula de resolución de controversias para iniciar un procedimiento $\operatorname{arbitral}^{40}$.

El artículo 28 de la Convención de Viena sobre el derecho de los tratados dispone que las disposiciones de un tratado no obligarán a una parte respecto de ningún acto o hecho que haya tenido lugar con anterioridad a la fecha de entrada en vigor, a menos que se diga lo contrario. Una controversia previa a la entrada en vigor del Convenio CIADI o a la del AII no estará cobijada por el instrumento internacional. No obstante, este aspecto temporal presenta varias dificultades para el tribunal a la hora de esclarecer si los hechos que dieron lugar a la controversia persisten en el tiempo, o si los mismos hacen parte de una controversia posterior que tiene relación con la primera controversia, para determinar si existe una unidad de materia y temporal entre los hechos y disputas que hayan surgido con anterioridad y posterioridad a la entrada en vigor del AII.

En relación con la inversión establecida antes de la entrada en vigor del AII, dependerá lo que diga este, pero la mayoría de los AII guardan silencio al respecto. A pesar de ello, la generalidad es que estos instrumentos protegen la inversión anterior y posterior a la entrada en vigencia de cada AII.

\subsection{Estándares de protección a la inversión extranjera}

Para entender los casos que se van a presentar más adelante es preciso comprender primero algunos de los estándares para la protección de la inversión extranjera a partir de la experiencia de otros países. A continuación se pasa a explicar someramente las siguientes protecciones sustantivas ${ }^{41}$ : trato justo y equitativo, trato nacional, cláusula de la nación más favorecida, cláusula paraguas y expropiación indirecta.

\subsubsection{Trato justo y equitativo}

Este es el estándar más invocado y el de mayor relevancia en las disputas de arbitraje internacional, por el carácter absoluto que presenta ${ }^{42}$. El propósito de esta cláusula es llenar los vacíos que puedan dejar otros estándares específicos para que el inversionista pueda obtener el grado de protección

40 PÉREZ, Y. Objeciones a la jurisdicción arbitral de CIADI. Cuadernos de Derecho Transnacional, Universidad Carlos III de Madrid. Vol. 4, n. ${ }^{\circ}$ 1, 2012, 316-333.

41 Los estándares de protección encontrados en los AII y en el derecho internacional son: trato justo y equitativo, seguridad y protección plenas, cláusula paraguas, debido proceso, acceso a la justicia y denegación de justicia, estados de emergencia, preservación de derechos, medidas arbitrarios o discriminatorias, trato nacional, nación más favorecida, transferencia de fondos y compensación por expropiación.

42 Schreuer, C. Fair and Equitable Treatment in Arbitral Practice. The Journal of World Investment and Trade. Vol. 6, n. ${ }^{\circ}$ 3, 2005, 357-386. 
otorgada por los $\mathrm{AII}^{43}$. Numerosos casos han tratado de definir el concepto de trato justo y equitativo, pero la violación a este estándar es evaluada en cada caso en particular. El concepto de trato justo y equitativo debe interpretarse a la luz de su significado ordinario, el derecho internacional y el principio de buena $\mathrm{fe}^{44}$.

Este criterio ha sido mayormente aplicado en casos de protección a la transparencia, estabilidad y expectativas legítimas del inversionista ${ }^{45}$, pero también para el cumplimiento de obligaciones contractuales ${ }^{46}$, el cual admite la posibilidad de que el incumplimiento de una obligación contractual pueda elevarse a status de protección internacional mediante este estándar de protección, dibujando una línea borrosa entre aquello que pueda ser derivado de la relación comercial y que de una inversión extranjera. Este estándar también se ve reflejado en la falta del debido proceso ${ }^{47}$ cuando hay denegación de justicia en el Estado receptor o a través de acciones u omisiones ejecutivas y legislativas; así como cuando se está ante la violación del principio de buena $\mathrm{fe}^{48} \mathrm{y}$ cuando haya actuaciones arbitrarias y discriminatorias ${ }^{49}$.

43 Ibíd.

44 Los casos más relevantes que han definido este concepto son: MTD Equity Sdn. Bhd. and MTD Chile S.A. vs. República de Chile, Caso CIADI n. ${ }^{\circ}$ ARB/01/7; S.D. Myers, Inc. v. Government of Canada, Caso uncitral; Saluka Investments B.V. v. The Czech Republic, Caso UnCITRAL; Técnicas Medioambientales Tecmed, S.A. vs. Estados Unidos Mexicanos, Caso NCIADI O. ARB (AF)/00/2; Waste Management, Inc. vs. Estados Unidos Mexicanos, Caso CIADI n. ${ }^{\circ}$ ARB/98/2.

45 Ver CMS Gas Transmission Company vs. República de Argentina, Caso CIADI n. ${ }^{\circ}$ ARB/01/8; Gami Investments, Inc. vs Estados Unidos Mexicanos, Caso UnCITRAL; Marvin Roy Feldman Karpa v. Estados Unidos Mexicanos, Caso CIADI n. ${ }^{\circ}$ ARB(AF)/99/1; Mondev International Ltd. v. United States of America, Caso CIADI n. ${ }^{\circ}$ ARB(AF)/99/2; S.D. Myers, Inc. v. Government of Canada, Caso unCiTRaL; Southern Pacific Properties (Middle East) Limited v. Arab Republic of Egypt, Caso CIADI n. ${ }^{\circ}$ ARB $/ 84 /$.

46 Ver Consortium RFCC v. Royaume du Maroc, Caso CIADI n. ${ }^{\circ}$ ARB/00/6; Mondev International Ltd. v. United States of America, Caso CIADI n. ${ }^{\circ}$ ARB(AF)/99/2; Noble Ventures, Inc. v. Romania, Caso CIADI n. ${ }^{\circ}$ ARB $/ 01 / 11$; SGS Société Générale de Surveillance S.A. v. Republic of the Philippines, Caso CIADI n. ${ }^{\circ}$ ARB/02/6.

47 Ver International Thunderbird Gaming Corporation v. Estados Unidos Mexicanos, Caso Uncitral; Loewen Group, Inc. and Raymond L. Loewen v. United States of America, Caso CIADI n. ${ }^{\circ}$ ARB(AF)/98/3; Metalclad Corporation v. Estados Unidos Mexicanos, Caso CIADI n. ${ }^{\circ}$ ARB(AF)/97/1; Middle East Cement Shipping and Handling Co. S.A. v. Arab Republic of Egypt, Caso CIADI n. ${ }^{\circ}$ ARB/99/6; Técnicas Medioambientales Tecmed, S.A. v. Estados Unidos Mexicanos, Caso CIADI n. ${ }^{\circ}$ ARB (AF)/00/2.

48 Ver Bayindir Insaat Turizm Ticaret Ve Sanayi A.S.v. Islamic Republic of Pakistan, Caso CIADI n. ${ }^{\circ}$ ARB/03/29; CMS Gas Transmission Company v. República de Argentina, Caso CIADI n. ${ }^{\circ}$ ARB/01/8; Saluka Investments B.V. v. The Czech Republic, Caso UnCITRAL; Waste Management, Inc. v. Estados Unidos Mexicanos, Caso CIADI n. ${ }^{\circ} \mathrm{ARB} / 98 / 2$.

49 Ver Pope \& Talbot Inc. v. The Government of Canada, Caso uncitral; S.D. Myers, Inc. v. Government of Canada, Caso UNCITRAL. 


\subsubsection{Trato nacional}

La cláusula de trato nacional supone que el trato a los inversionistas extranjeros no sea menos favorable en igualdad de condiciones de competencia que aquel concedido a los inversionistas nacionales en la aplicación de regulaciones o prácticas adoptadas por el Estado receptor.

Para la aplicación de esta cláusula debe analizarse si el inversionista nacional y el extranjero están en una situación comparable, y determinarse si el tratamiento al inversionista extranjero es menos favorable que el tratamiento atribuido a los inversionistas nacionales ${ }^{50}$. Existen cuatros elementos que se tienen en cuenta para la aplicabilidad de este estándar ${ }^{51}$ : i) concesión de una garantía, es decir, establecer un "piso" para que el trato que se otorgue efectivamente al nacional no pueda ser por debajo del cual se trate al inversionista extranjero; ii) parámetro de comparación; iii) circunstancias similares para comparar, y iv) etapas en las que se otorga, pre- establecimiento de la inversión o post-establecimiento de la misma.

\subsubsection{Cláusula de la nación más favorecida}

Esta cláusula se instrumentó en el artículo 1. ${ }^{\circ}$ del Acuerdo General sobre Aranceles Aduaneros y Comercio (GATT). Este estándar implica que los Estados parte deben proporcionar a los inversionistas un trato no menos favorable que aquel otorgado en situaciones similares a inversionistas provenientes de un tercer Estado. El alcance de este estándar estará delimitado por los beneficios otorgados al tercer Estado ${ }^{52}$.

Se ha generado un debate en torno a si esta cláusula comprende solo beneficios sustantivos o también procedimentales, como los elementos de resolución de $\operatorname{conflictos}^{53}$. Las disposiciones procesales pactadas en los AII y su posible aplicación e integración a otros sólo podrían operar si ambos esquemas del AII con el que se está tratando una aplicación más favorable es compatible con el esquema del AII por el que está cubierto el inversionista ${ }^{54}$.

50 Dolzer, R. y Schreuer, C. Principles of International Investment Law, New York, Oxford University Press, 2008, 179.

51 Ampuero, A. Trato nacional, trato de nación más favorecida, nivel mínimo de trato y expropiación en los Acuerdos Internacionales de Inversión; disponible en: http://www.oas.org/ es/sla/ddi/docs/publicaciones_digital_xxxIv_curso_derecho_internacional_2007_Ana_A_Ampuero_Miranda.pdf [Consultado el 20 de febrero de 2017]

52 Dolzer y Schreuer, ob. cit., 186.

53 MCCLURE, M. Most favoured nation clauses - No favoured view on how they shouldbe interpreted; disponible en: http://kluwerarbitrationblog.com/2011/07/25/most-favoured-nationclauses-no-favoured-view-on-how-they-should-be-interpreted/ [Consultado el 20 de febrero de 2017].

54 Bohoslavsky, J. P. Tratados de protección de las inversiones e implicaciones para la formulación de políticas públicas (especial referencia a los servicios de agua potable y sanea- 
La aplicación de este estándar en aspectos procedimentales ha sido aceptada por tribunales arbitrales ${ }^{55}$ : así, en Emilio Agustín Maffezini v. España el tribunal advirtió que la cláusula de la nación más favorecida debe operar con una extensión limitada evitando promover el fenómeno de Treaty-shopping ${ }^{56}$.

\subsubsection{Cláusula paraguas}

La cláusula paraguas tiene como objeto garantizar el cumplimiento de compromisos adquiridos respecto de las inversiones en sede de los contratos de inversión celebrados. Esta cláusula es de carácter residual, ya que incluye dentro del ámbito del respectivo AII aquellas acciones ejercidas por el Estado que no se configuran necesariamente como expropiatorias ni como denegatorias de trato justo y equitativo ${ }^{57}$. La importancia de esta cláusula es que excluye la posibilidad de someter la controversia que se suscite con ocasión del cumplimiento del contrato a un arbitraje internacional de inversión; es decir, solo es viable someter tal controversia al mecanismo de solución de conflictos del tratado si el objeto de la controversia es relativo al concepto de inversión. Así lo expresaron los árbitros en El Paso Energy International Company v. Argentina:

... una cláusula paraguas no puede transformar cualquier reclamo contractual en un reclamo basado en un tratado, ya que esto entrañaría necesariamente que todos los compromisos del Estado respecto de las inversiones, aún los de menor importancia, se transformarían en reclamos basados en un tratado. [...] sería, en verdad, extraño que la aceptación del TBI entrañaría la responsabilidad internacional del Estado de las inversiones extranjeras incorporadas en el Tratado y convirtiera al Estado responsable de las violaciones de cualquier compromiso del derecho nacional o internacional, con respecto a las inversiones ${ }^{58}$.

El alcance de la cláusula paraguas está limitado a la protección de las inversiones contra medidas gubernamentales que violen los principios de protección del acuerdo internacional, y no aquellos derivados de una actividad comercial.

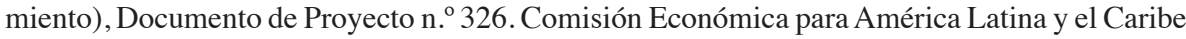
(CEPAL); disponible en: http://repositorio.cepal.org/handle/11362/3769 [Consultado el 20 de febrero de 2017].

55 Plama Consortium Limited v. Republic of Bulgaria, Caso CIADI n. ${ }^{\circ}$ ARB/03/24.

56 García y Arévalo, ob. cit., 263.

57 Sommer, C. La aplicación de estándares de protección de inversiones extranjeras. Una mirada desde los casos argentino. ACDI-Anuario Colombiano de Derecho Internacional, Universidad del Rosario. Vol. 6, 2014, 95-130.

58 El Paso Energy International Co. vs. Argentina, Caso CIADI n. ${ }^{\circ}$ Arb/03/15, Laudo del 27 de abril de 2006, pár. 82 . 


\subsubsection{Expropiación indirecta}

En el ejercicio de la soberanía es permitido que los Estados, para la protección del interés público, tomen medidas expropiatorias siempre que estas sean adoptadas por motivos de bienestar general, no sean discriminatorias o arbitrarias, se respete el debido proceso y se realice un pago pronto, adecuado y efectivo de la indemnización.

Como bien se sabe, la expropiación puede ser de dos tipos: directa e indirecta. La directa es aquella en la que se transfiere formalmente el derecho de dominio al Estado; actualmente esta no es tan común debido a que los Estados tratan de salvaguardar un ambiente de inversión favorable. En cuanto a la expropiación indirecta, esta es definida como "aquella en que el inversionista conserva el título legal de la propiedad pero ve limitados sus derechos de uso de la propiedad como consecuencia de una interferencia del Estado" ${ }^{59}$. La doctrina ha definido dos modalidades de expropiación indirecta, una progresiva y otra regulatoria ${ }^{60}$. La expropiación progresiva ("creeping expropiation") comprende una serie de medidas estatales, tomadas dentro de un periodo de tiempo, que resultan en la pérdida sustancial del valor de la inversión o en el control de su inversión. Este concepto fue traído por el tribunal en Generation Ukraine v. Ucrania; los ejemplos que han podido establecerse con otros casos arbitrales son: nombramiento de gerentes, desinversión forzada de las acciones de una empresa, interferencia en la administración de la empresa, impedimento de la distribución de utilidades, impuestos excesivos o arbitrarios ${ }^{61}$, entre otros.

La expropiación regulatoria ("regulatory expropiation") es aquella actuación propia del poder regulatorio que tiene el Estado que impacta el valor económico de la inversión. A pesar de que en principio podría pensarse que cualquier medida del gobierno pueda ser considerada como una expropiación indirecta, esto no es así, porque se podría llegar al absurdo de que todas las medidas tomadas por el Estado puedan ser consideradas como expropiatorias $^{62}$. Por lo tanto corresponde al tribunal estudiar en cada caso tres aspectos: i) la acción gubernamental; ii) la medida en la cual la acción del gobierno

59 PÁEz, M. La expropiación indirecta frente al CIADI: consideraciones para la autorregulación de los actos administrativo del Estado. Revista de Estudios Internacionales, Universidad de Chile. Vol. 39, n. ${ }^{\circ}$ 153, abril-junio de 2006, 5-36.

60 United Nations Conference on Trade and Development [UNCTAD]. (2000). Taking of property. Nueva York y Ginebra: Naciones Unidas.

61 Ver Pope \& Talbot Inc. v. The Government of Canada, Caso UncitraL; Biloune and Marine Drive Complex Ltd v. Ghana Investments Centre and the Government of, Ad hoc Tribunal (Reglas UNCITRAL). Decisión sobre jurisdicción y responsabilidad del 27 de octubre de 1989.

62 FAYA, A. ¿Cómo se determina una expropiación indirecta bajo tratados internacionales en materia de inversión? Un análisis contemporáneo. Instituto de Investigaciones Jurídicas, Universidad Nacional Autónoma de México; disponible en https://archivos.juridicas.unam.mx/ www/bjv/libros/7/3386/8.pdf [Consultado el 20 de febrero de 2017]. 
interfiere con expectativas inequívocas y razonables de la inversión, y iii) el impacto económico de la medida gubernamental, aunque este tenga un efecto adverso sobre el valor económico de una inversión, por sí mismo no implica que se haya producido una expropiación indirecta ${ }^{63}$.

Los tratados modernos, especialmente los suscritos con Estados Unidos, establecen circunstancias excepcionales para determinar cuándo los actos gubernamentales no son considerados como expropiatorios, correspondiendo a aquellos actos regulatorios no discriminatorios que estén diseñados para proteger aspectos del interés público como la salud pública, la seguridad y el medio ambiente. Sin embargo, en numerosos casos arbitrales ${ }^{64}$, aunque se alegue la regulación de medidas para proteger el interés público, los tribunales no las han considerado como tales, y sí por el contrario como actuaciones expropiatorias que afectan las expectativas de la inversión.

\section{CASOS DE ARBITRAJE INVERSIONISTA-ESTADO CONTRA COLOMBIA}

Debido al grado de confidencialidad que cobijan estos arbitrajes internacionales de inversión, los hechos de los casos que se enumeran a continuación son un resumen de la información conocida a través de diferentes fuentes. De cada caso se realiza un análisis de las vicisitudes que presentan los arbitrajes de inversión contra Colombia, en contraste con casos de otros países, según las alegaciones conocidas. Las siguientes observaciones son meras interpretaciones de cómo podrían ser llevados a cabo estos tribunales arbitrales, pudiendo diferir de la información oficial que se conozca cuando esta sea difundida.

\subsection{Glencore International A.G. and C.I. Prodeco S.A. v. República de Colombia (Caso CIADI $n .^{\circ}$ ARB/16/6)}

\subsubsection{Hechos}

Glencore International A.G. and C.I. Prodeco S.A. (en adelenate "Prodeco") -el tercer productor de carbón del país- presentó una demanda formal ante el CIADI conforme al artículo 37 (2)(a) del Convenio de este Centro, el 16 de marzo de 2016. El árbitro elegido por la multinacional fue Óscar Garibaldi,

63 La capacidad regulatoria ha sido reconocida por los tribunales arbitrales en Methanex Corporation v. United States of America, caso UnCITRAL; Saluka Investments B.V. v. The Czech Republic, Caso UnCITRAL, entre otros.

64 CMS Gas Transmission Company vs. República de Argentina, Caso CIADI n. ${ }^{\circ}$ ARB/01/8; S.D. Myers, Inc. v. Government of Canada, Caso UnCiTRAL; Técnicas Medioambientales Tecmed, S.A. v. Estados Unidos Mexicanos, Caso CIADI n. ${ }^{\circ}$ ARB (AF)/00/2. 
por parte de Colombia lo fue Christopher Thomas, y el presidente es Juan Fernández-Armesto ${ }^{65}$.

La reclamación formal contra el Estado colombiano versa sobre la sanción impuesta por la Contraloría General de la República por los ajustes hechos sobre el cálculo para liquidar las regalías y compensación por ingresos brutos pactado en el otrosí del contrato de concesión minera ${ }^{66}$ del Proyecto Calenturitas firmado en el año 2010. En el año 2015, la Contraloría General sancionó a Prodeco, al Ministro de Minas y Energía, al director de Ingeominas y al director técnico de esta entidad, de ese entonces, a pagar solidariamente la suma de \$60.023 millones, como consecuencia de la disminución de ingresos por regalías recibidos por el Estado, y obligó a la renegociación del contrato por no tener los estudios previos, ni la planeación necesaria que requería el contrato. La correspondiente multa fue pagada por la compañía de la filial suiza para evitar la caducidad del contrato; sin embargo, consideró que se trató de un detrimento patrimonial injustificado.

Según Prodeco, con esta negociación se buscaba un escenario más favorable para desarrollar sus inversiones con planes de expansión que la llevarían a aumentar su producción y a construir el puerto ${ }^{67}$. La compañía consideraba que si bien el valor de las regalías disminuía en los primeros años en el desarrollo de las obras, posteriormente ese valor se compensaba con el incremento en la producción de carbón en el Cesar ${ }^{68}$.

\subsubsection{Análisis del caso}

Si bien se desconocen los fundamentos de la demanda, del твi Suiza-Colombia se destacan dos cláusulas relevantes para este caso: la cláusula paraguas contenida en el artículo 10.2 y la expropiación indirecta contenida en el artículo 6.

La cláusula paraguas tiene por objeto garantizar la observancia de las obligaciones asumidas por el Estado en los acuerdos suscritos con el inversionista, y proteger a este último de aquellas medidas estatales de carácter soberano que afecten las condiciones de la inversión.

65 A la fecha de esta publicación, el Estado colombiano había presentado solicitud para abordar las objeciones a la jurisdicción como una cuestión preliminar (2 de febrero de 2017).

66 Otrosí n. ${ }^{\circ} 8$ del Contrato 044/89. La discusión acerca de los términos de renegociación del contrato de concesión fue de alrededor de dos años.

67 El 9 de febrero de 2016 la Superintendencia de Industria y Comercio (SIC) formuló pliego de cargos contra Puerto Nuevo y Prodeco por obstruir el uso del puerto público a terceros exportadores de carbón; disponible en: http://www.sic.gov.co/drupal/noticias/pliego-de-cargoscontra-PUERTO-NUEVO-y-PRODECO-por-obstruir-el-uso-del-puerto-publico-a-terceros-exportadoresde-carbon [Consultado el 21 de junio de 2016].

68 Glencore prepara demanda contra el Estado. Dinero. Bogotá, 1. ${ }^{\circ}$ de marzo de 2016; disponible en: http://www.dinero.com/pais/articulo/glencore-va-a-demandar-al-estado-porproteccion-a-la-inversion/220945 [Consultado el 21 de febrero de 2017]. 
De la lectura estricta del artículo 10.2 se desprende que la aplicación de esta disposición solo es posible cuando exista una controversia que verse sobre un acuerdo escrito entre el gobierno central o sus agencias respecto a una inversión específica. Si apelamos al artículo 31 del Convenio de Viena sobre el derecho de los tratados, los acuerdos internacionales deben interpretarse conforme al sentido corriente que haya de atribuirse a los términos de los mismos, con lo cual podría considerarse en primera instancia que ampararse en esta disposición sería aventurado porque la controversia versa sobre la multa impuesta por un ente de control, y no sobre el contrato en sí mismo.

Pero lo interesante en este tratado no es lo explicado anteriormente, sino que esta cláusula fue excluida del consentimiento para albergar arbitrajes inversionista-Estado según el artículo 11.3 del TBI Suiza-Colombia, que reza: “(3) Cada Parte da su consentimiento incondicional e irrevocablemente al sometimiento de una disputa de inversión a un arbitraje internacional, de acuerdo al párrafo 2 anterior, excepto por disputas en referencia al artículo 10 párrafo 2 de este Acuerdo".

Siendo esto así, podría pensarse muy arriesgada la posición de los demandantes al tratar de salvaguardar su interés en la cláusula paraguas, pues de ser así el Estado colombiano podría objetar la jurisdicción del tribunal arbitral.

En cuanto a la expropiación indirecta, no toda medida estatal puede considerarse expropiatoria solo porque tiene un efecto adverso al valor económico de la inversión. En el TBI con Suiza nada se dice en relación con aquellas circunstancias excepcionales en que los actos gubernamentales no son considerados como expropiación indirecta; como son aquellos actos regulatorios no discriminatorios que estén diseñados para proteger aspectos del interés público como la salud pública, la seguridad y el medio ambiente.

Bajo este análisis, la sanción impuesta por la Contraloría General es un acto administrativo de responsabilidad fiscal que tiene como finalidad proteger el interés nacional, como es el patrimonio público, pero no tiene la virtualidad de un acto regulatorio. No se trata tampoco de una serie de medidas tomadas dentro de un periodo de tiempo que puedan encajar en el concepto de expropiación progresiva, que aunque afectó el valor económico de la inversión, no todo efecto desfavorable al valor económico de la misma puede considerarse expropiación indirecta. Así lo señaló el tribunal arbitral de Too v. Greater Modesto Insurance Associates ${ }^{69}$, en el que afirmó que un Estado no es responsable por los daños a la propiedad u otras desventajas económicas resultantes de cualquier acción que sea comúnmente aceptada dentro de las facultades soberanas de los Estados, siempre y cuando no sea discriminatoria ni esté diseñada para provocar que el extranjero abandone su propiedad a favor del Estado o la venda a un precio forzado.

69 Emmanuel Too v. Greater Modesto Insurance Associates and the United States of America, Laudo de diciembre 29 de 1989. 
Ahora bien, se trata de una conducta del Estado en el ejercicio de su soberanía como es el control fiscal del Estado, así no se deprenda de la entidad con la que se suscribió el contrato o de un acto del poder ejecutivo. El artículo 4..$^{\circ}$ sobre la responsabilidad de los Estados por hechos internacionalmente ilícitos ${ }^{70}$ considera como hecho del Estado el comportamiento de cualquier órgano, sea una persona o una entidad que ejerza cualquier tipo de funciones al interior del Estado; siendo así, independientemente de que se trate de una medida tomada por un órgano autónomo e independiente y no del gobierno central o de sus agencias, el Estado colombiano debe responder por la conducta perjudicial que le cause a los inversionistas extranjeros.

Por último, en la adición al artículo 11 relativo a la resolución de controversias inversionista-Estado se señala expresamente que un tribunal arbitral "no será competente para revisar la legalidad de una ley doméstica o regulación bajo el ordenamiento constitucional o legal de la Parte concerniente". Si aplicamos el contenido de esta disposición por analogía, a la legalidad de los actos administrativos, el tribunal arbitral internacional no sería competente; lo cual tendría sentido, por ser al Estado, y no un tribunal arbitral, a quien le compete realizar el estudio de legalidad de sus actos administrativos.

\subsection{Eco Oro Minerals Corp. v. República de Colombia (Caso CIADI n. ${ }^{\circ}$ ARB/16/41)}

\subsubsection{Hechos}

Eco Oro Minerals Corp (en adelante "Eco Oro"), empresa dedicada a la exploración y desarrollo de metales preciosos, presentó en marzo de 2016 una reclamación formal en el marco del capítulo de inversión del TLC con Canadá. El 29 de diciembre de 2016, sin llegar a un arreglo directo entre las partes, la compañía presentó solicitud de arbitraje ante el $\mathrm{CIADI}^{71}$.

La compañía fundamenta su pleito en las actuaciones y omisiones del Gobierno Nacional en la delimitación del Páramo Santurbán ${ }^{72}$, al coincidir con la exploración de la mina Angostura en Santander ${ }^{73}$, debido a que la

70 Resolución 56/83 de las Naciones Unidas.

71 A la fecha de la publicación de este artículo el tribunal arbitral no se había constituido aún.

72 Mediante Resolución 2090 de 2014, del Ministerio de Ambiente y Desarrollo Sostenible, se delimitó el Páramo de Santurbán-Berlín.

73 Eco Oro Minerals notifies Colombian Government of Investment Dispute. Eco Oro. Vancouver, Canadá, March 17 2016; disponible en: http://www.eco-oro.com/s/NewsReleases. asp?ReportID=741972\&_Type=News-Releases\&_Title=Eco-Oro-Minerals-Notifies-ColombianGovernment-of-Investment-Dispute [Consultado el 22 de febrero de 2017]. 
Corte Constitucional ${ }^{74}$ amplió la prohibición de actividades mineras en las zonas de páramo.

La Corte Constitucional declaró inexequibles, entre otros, los incisos primero, segundo y tercero del primer parágrafo del artículo 173 de la Ley 1753 de 2015, por el desconocimiento al deber constitucional de proteger áreas de especial importancia ecológica poniendo en riesgo el acceso de toda la población al derecho fundamental al agua en condiciones de calidad.

Posterior al fallo de la Corte Constitucional, el 2 de agosto de 2016, la Agencia Nacional de Minería (ANM) emitió la Resolución vsC 829 a través de la cual se privan los derechos mineros de la compañía respecto del 50.73\% dentro del área de concesión de la zona de preservación del Páramo Santurbán.

\subsubsection{Análisis del caso}

El Estado colombiano podría respaldarse en el artículo 815 del TLC CanadáColombia, el cual dispone que una inversión no podrá fomentarse si esto implica desmejorar las condiciones medioambientales como una forma de incentivar el establecimiento, adquisición, expansión o retención en el territorio de esa inversión. En caso de que se haya ofrecido este tipo de incentivos, este asunto se abordará a través de consultas e intercambio de información por los Estados parte. Esta disposición está excluida de la aplicación del mecanismo de solución de controversias inversionista-Estado según los artículos 820.1(a) y 837, en concordancia con el Anexo 837 del TLc Canadá-Colombia.

Aun así, el demandante podría alegar la existencia de una expropiación indirecta sin compensación. El Anexo 811 "Expropiación Indirecta" señala las circunstancia a evaluar para determinar si hubo una expropiación indirecta y establece que aquellas medidas no discriminatorias de un Estado receptor que sean diseñadas para proteger el bienestar público, como el medio ambiente, no constituyen expropiación indirecta, siempre que la medida o la serie de medidas no puedan ser razonablemente percibidas como que fueron adoptadas de buena fe.

Sobre la base de la expropiación indirecta, el demandante podría reclamar que su inversión estaba fundamentada en una expectativa legítima, la cual se ha tratado en varios casos arbitrales ${ }^{75}$. En Thunderbird v. México el tribunal concluyó que no es procedente una indemnización en caso de expropiaciones reglamentarias cuando se demuestre que la inversión nunca gozó de un derecho adquirido en la actividad económica. En relación con el concepto de "expectativas legítimas" este tribunal lo definió como "una situación en que la

74 Sentencia C-035 del 8 de febrero de 2016.

75 Ver Técnicas Medioambientales Tecmed, S.A.v. Estados Unidos Mexicanos, Caso CIADI n. ${ }^{\circ}$ ARB (AF)/00/2; Azurix Corp. v. República de Argentina, Caso CIADI n. ${ }^{\circ}$ ARB/01/12; Metalclad Corporation v. Estados Unidos Mexicanos, Caso CIADI n. ${ }^{\circ}$ ARB(AF)/97/1. 
conducta de la Parte Contratante crea expectativas razonables y justificables para que un inversionista (o una inversión) actúe basándose en esa conducta, por lo cual el hecho de que una Parte del TLCAN no cumpla esas expectativas puede causar perjuicios al inversionista (o a la inversión)" "76.

Adicionalmente, la reclamación también podría fundamentarse en la violación al artículo 805 del TLC referente al nivel mínimo de trato establecido por las normas del derecho internacional, el cual comprende el trato justo y equitativo y la protección y seguridad plenas.

Frente a este último punto, en un caso similar, Glamis Gold v. Estados Unidos, la compañía, empresa minera canadiense, demandó a Estados Unidos por las medidas tomadas por el Estado de California que protegían el medio ambiente y las comunidades indígenas de los impactos de la minería a cielo abierto. La reclamación se fundamentó en la violación a los artículos 1105 (nivel mínimo de trato conforme con las normas del derecho internacional y el trato justo y equitativo) y 1110 (expropiación) del TLCAN. El tribunal denegó las pretensiones del demandante señalando que frente a la expropiación, las medidas tomadas no causaron un suficiente impacto económico que pudiera tener el efecto de una expropiación ${ }^{77}$. En relación con el trato justo y equitativo el tribunal manifestó:

... para constituir una violación del estándar mínimo de trato que fija el derecho internacional consuetudinario, tal como fue codificado en el artículo 1105 del TLCAN, un acto debe ser lo suficientemente escandaloso y grave -una denegación de justicia flagrante, evidente arbitrariedad, injusticia descarada, una completa falta de debido proceso, una evidente discriminación, o una manifiesta falta de motivos- como para no cumplir con los estándares internacionales aceptados y constituir una violación del artículo $1105^{[78]}$.

Otros casos de concesiones mineras no han tenido un concepto tan favorable para el Estado ${ }^{79}$. De hecho, de un análisis sistemático de la "jurisprudencia arbitral" en este aspecto pareciera que los laudos son a favor de las pretensiones del inversionista, condenando a los Estados a pagar indemnizaciones cuantiosas a favor de este. Queda entonces esperar que la defensa del Estado colombiano sea lo suficientemente robusta para alcanzar un laudo favorable.

76 International Thunderbird Gaming Corporation v. Estados Unidos Mexicanos, Caso UNCITRAL. Laudo arbitral del 26 de enero de 2006, pár. 208.

77 Glamis Gold, Ltd. v. The United States of America, Caso unciTral. Laudo arbitral del 8 de enero de 2009 , pár. 536.

78 Ibíd., 627.

79 Ver Crystallex International Corporation v. República Bolivaria de Venezuela, Caso CIADI n. ${ }^{\circ}$ ARB(AF)/11/2; Gold Reserve Inc. v. Bolivaria de Venezuela, Caso CIADI n. ${ }^{\circ}$ ARB(AF)/09/1; Khan Resources Inc., Khan Resources B.V., and Cauc Holding Company Ltd. v. The Government of Mongolia, Caso uncitraL; Rusoro Mining Ltd. v. Bolivarian Republic of Venezuela, ICSID Case n. ${ }^{\circ}$ ARB(AF)/12/5. 
5.3. América Móvil S.A.B. de C.V.v. República de Colombia (Caso CIADI $\left.n{ }^{\circ} A R B(A F) / 16 / 5\right)$

\subsubsection{Hechos}

El 3 de octubre de 2016, América Móvil S.A.B. de C.V. (en adelante "America Móvil"), matriz de Comunicación Celular, S.A. (en adelante "Comcel"), registró la solicitud de establecimiento de un procedimiento de arbitraje. Los árbitros elegidos fueron José Martínez de Hoz (demandante) y Rodrigo Oreamuno (demandado) ${ }^{80}$.

La disputa versa sobre la cláusula de reversión de los contratos de concesión suscritos en marzo de 1994, en los que existía la obligación por parte de Comcel y Colombia Telecomunicaciones SA ESP (en adelante "Telefónica") de devolver los activos para la operación del servicio de telefonía móvil celular, como eran las torres, antenas y cableado, así como $25 \mathrm{MHz}$ de espectro en la banda de $850 \mathrm{MHz}$ y otros $15 \mathrm{MHz}$ más en las frecuencias de los 1.900 $\mathrm{MHz}$ cuando vencieran sus permisos de explotación de servicios.

Posteriormente, las leyes 422 de 1998 y 1341 de 2009 eliminaron la obligación de reversión de infraestructura, pero mantuvieron la reversión de las frecuencias radioeléctricas asignadas, sin hacer referencia alguna sobre los contratos vigentes al momento de entrada en vigencia de la Ley de 1998. Es decir que los contratos originalmente firmados no fueron modificados con la entrada en vigencia de estas leyes, y por tanto existe la obligación de revertir los bienes entre 1994 a 1998. La Corte Constitucional en Sentencia C-555 de 2013 declaró la exequibilidad de ambas normas, pero solo bajo el entendido de que en los contratos de concesión suscritos antes de la entrada en vigencia de estas normas se debía respetar el contenido de las cláusulas de reversión, en ellas acordadas, y advirtió que podría haber una compensación económica a favor de estos operadores de telefonía en relación con la infraestructura instalada, al estar siendo empleada para la prestación de otros servicios adicionales a los concesionados inicialmente.

Debido a que no se logró llegar a un acuerdo en relación con el monto de la compensación de los activos a revertir y América Móvil considera vulnerados sus derechos por el supuesto cambio de reglas frente a la reversión de redes e infraestructura que se instalaron desde 1994 a 1998 para la prestación del servicio ${ }^{81}$, está solicitando una indemnización equivalente al valor justo de mercado que tendría la inversión en el momento de la expropiación más los intereses correspondientes. Así mismo alega la violación al estándar del

80 Los datos son los registrados a la fecha de la elaboración de este documento.

81 El magnate Carlos Slim buscará indemnización del Gobierno Colombiano. El Tiempo. Bogotá, 17 de marzo de 2016; disponible en: http://www.eltiempo.com/archivo/documento/ CMS-16538841 [Consultado el 22 de febrero de 2017]. 
trato justo y equitativo, y el nivel mínimo de trato exigido por el derecho consuetudinario internacional, por la cláusula de nación más favorecida ${ }^{82}$.

Paralelo a este arbitraje internacional de inversión, el Ministerio de Tecnologías de la Información y Comunicaciones -MinTIC- instauró un arbitraje en Colombia con las dos empresas (Comcel y Telefónica) para dirimir la controversia sobre la liquidación de los contratos de concesión con ambos operadores. Uno de los principales retos que va a tener este tribunal nacional es definir cuáles son los activos que son objeto de devolución y cómo se van a tasar los mismos, ya que a la fecha no ha sido posible.

\subsubsection{Análisis del caso}

Según los hechos y las declaraciones encontradas, esta demanda arbitral se fundamenta principalmente en la cláusula de la nación más favorecida, aunque no se puede entrar a dilucidar con qué tratado de un tercer país se realiza la comparación para esbozar las posibles condiciones menos favorables que presume tener América Móvil.

La aplicación de la cláusula de la nación más favorecida admite una protección sustantiva con otros estándares ${ }^{83}$ como el trato justo y equitativo y compensación por expropiación, como se pretende en el presente caso.

En MTD v. Chile la cláusula de la nación más favorecida se matizó con los aspectos del trato justo y equitativo. El tribunal arbitral concluyó que el significado de trato justo y equitativo debe interpretarse de la manera más adecuada para cumplir el objetivo del TBI de proteger las inversiones y crear condiciones favorables a las inversiones, por lo que debían considerarse como parte de las protecciones del тві las incluidas en el тві de Dinamarca y de Croacia ${ }^{84}$.

Por otra parte, en Tecmed v. México el tribunal arbitral manifestó:

El Tribunal Arbitral considera que esta disposición [trato justo y equitativo] del Acuerdo, a la luz de los imperativos de buena fe requeridos por el derecho internacional, exige de las Partes Contratantes del Acuerdo brindar un tratamiento a la inversión extranjera que no desvirtúe las expectativas básicas en razón de las cuales el inversor extranjero decidió realizar su inversión. Como parte de tales expectativas, aquél cuenta con que el Estado receptor de la inversión se conducirá

82 Ahora sí: Claro demanda a Colombia por violaciones al tLc con México. Dinero. Bogotá, 23 de agosto de 2016; disponible en: http://www.dinero.com/empresas/articulo/claro-demandaa-colombia-por-violaciones-al-tlc-con-mexico/231125 [Consultado el 22 de febrero de 2017].

83 Monroy, M. C. La cláusula de la nación más favorecida en los tratados bilaterales de inversión vigentes para Colombia y sus efectos de acuerdo con laudos arbitrales CIADI. Revista de Derecho Público, Universidad de los Andes. №. 35, julio-diciembre, 2015, 1-34.

84 MTD Equity Sdn. Bhd. and MTD Chile S.A. v. República de Chile, Caso CIADI n. ${ }^{\circ}$ ARB/01/7, pár. 103 y 104. 
de manera coherente, desprovista de ambigüedades y transparente en sus relaciones con el inversor extranjero, de manera que éste pueda conocer de manera anticipada, para planificar sus actividades y ajustar su conducta, no sólo las normas o reglamentaciones que regirán tales actividades, sino también las políticas perseguidas por tal normativa y las prácticas o directivas administrativas que les son relevantes [...] El inversor extranjero también espera que el Estado receptor actuará de manera no contradictoria; es decir, entre otras cosas, sin revertir de manera arbitraria decisiones o aprobaciones anteriores o preexistentes emanadas del Estado en las que el inversor confió y basó la asunción de sus compromisos y la planificación y puesta en marcha de su operación económica y comercial ${ }^{85}$.

Lo expresado por este último laudo puede aplicarse a favor del Estado colombiano, bajo la óptica de que el contrato se celebró en 1994, y a la fecha de suscripción del mismo el inversionista conocía de manera anticipada la obligación de revertir los activos; de manera que no se desvirtuaron las expectativas legítimas esperadas con la inversión. De igual forma, tal como lo indicó la Corte Constitucional, estos "contratistas tuvieron la oportunidad de hacer los cálculos amortizatorios para recuperar la inversión de los bienes y elementos necesarios para el cumplimiento del servicio", con lo cual no se afectaría el equilibrio contractual por la reversión de la infraestructura.

En relación con una indemnización equivalente al valor justo de mercado que tendría la inversión en el momento de la expropiación, la misma encuentra soporte en la cláusula de la nación más favorecida. Este concepto fue esclarecido por el tribunal de CME v. República Checa al señalar que la determinación de la compensación sobre la base del "valor justo de mercado" se da con relación a los hechos y circunstancias en un punto del tiempo; para el tribunal el valor justo del mercado es una compensación que represente el valor genuino de la propiedad afectada ${ }^{86}$.

Por último, mucho dependerá de lo que se decida en el tribunal local para la resolución del tribunal internacional.

\subsection{Cosigo Resources, Ltd., Cosigo Resources Sucursal Colombia,} Tobie Mining and Energy, Inc. v. República de Colombia, Caso UNCITRAL

\subsubsection{Hechos}

En febrero de 2016, estas compañías presentaron formalmente una demanda arbitral bajo el reglamento CNUDMI ante la Asociación Americana de Arbitraje (AAA) contra el Estado colombiano por la expropiación sin compensación basada en un fraude. De acuerdo con los fundamentos de la reclamación, los

85 Técnicas Medioambientales Tecmed, S.A. v. Estados Unidos Mexicanos, Caso CIADI n. ${ }^{\circ}$ ARB (AF)/00/2. Lauro arbitral del 29 de mayo de 2003, pár. 154.

86 CME Czech Republic B.V. v. The Czech Republic, Caso UnCITRAL. 
accionantes buscan una indemnización por 16.500 millones de dólares, que corresponde al valor ponderado del oro que hubiera podido extraerse, más 11 millones de dólares por los gastos asumidos para la preparación del sitio y la obtención de la concesión minera ${ }^{87}$.

La controversia versa sobre la fecha de creación del Parque Nacional Natural Yaigojé-Apaporis ${ }^{88}$ (27 de octubre de 2009), dos días antes de la suscripción del contrato de concesión minera IGH-15001X (29 de octubre de 2009) correspondiente a la concesión Taraira Sur.

Como consecuencia de la creación del parque nacional, en julio de 2011 Ingeominas profirió la Resolución DSM 0112 ordenando el retiro y desalojo inmediato de todas las obras y labores mineras, por encontrarse superpuestas totalmente al área delimitada como Parque Natural Yaigojé-Apaporis. Aunado a lo anterior, en noviembre de 2015, el Tribunal Administrativo de Cundinamarca declaró la nulidad absoluta del contrato IGH-15001X por objeto ilícito, así como su inscripción en el Registro Nacional Minero, por la protección especial que tienen los parques nacionales conforme a las normas nacionales y la prohibición de realizar actividades mineras en estas zonas. Esta sentencia fue apelada por Tobie Mining and Energy, Inc (en adelante "Tobie Mining") y se encuentra en trámite de segunda instancia ante el Consejo de Estado.

Por otra parte, la Asociación de Comunidades Indígenas de Taraira y Vaupés (ACITAVA) presentó una acción de tutela respecto del proceso con el que se creó el Parque Nacional Natural Yaigojé-Apaporis por atentar contra los derechos fundamentales a la identidad cultural, a la participación en condiciones de igualdad y al debido proceso en el desarrollo del derecho de consulta previa. La Corte Constitucional en sentencia del 17 de junio de $2014^{[89]}$ negó las pretensiones de ACITAVA y ordenó la suspensión de cualquier actividad de exploración y explotación minera, manifestando además que hubo una "injerencia indebida" por parte de Tobie Mining. En esta sentencia la Corte solicita al Ministerio del Interior y de Justicia - Dirección Indígenas y Minorías y al Ministerio de Ambiente Vivienda y Desarrollo Territorial "que evalúen la actuación de la empresa Cosigo Frontier Mining Corporation dentro del proceso de consulta previa revisado en esta sentencia y, de encontrarlo pertinente, inicien las acciones legales correspondientes".

87 La información de este caso se encuentra disponible en Italaw http://www.italaw.com/ cases/3961 [Consultado el 21 de febrero de 2017]. A la fecha de elaboración de este documento la última actuación registrada fue la respuesta de Colombia a la solicitud de arbitraje. Brian Coleman fue el árbitro elegido por los demandantes y Brigitte Stern el árbitro para Colombia; el tercer árbitro (presidente del tribunal) es escogido por ambos árbitros, y de no llegar a un acuerdo el Secretario General del CIADI actuará como autoridad nominadora y designará a dicho Presidente de conformidad con el artículo 10.19 del TLC.

88 Resolución 2079 del 27 de octubre de 2009 del Ministerio de Ambiente, Vivienda y Desarrollo Territorial.

89 Sentencia T-384A/14, M.P.: Gabriel Eduardo Mendoza Martello. 
Según lo alegado por los accionantes, la aprobación técnica del contrato de concesión minera fue hecha en 2008, y su aprobación legal en abril de 2009; por numerosos retardos no justificados de Ingeominas, el contrato de concesión fue suscrito el 29 de octubre de 2009, el mismo día que la resolución que creaba el Parque Natural Yaigojé-Apaporis fue publicada. Para las compañías, la demora se debió a un intento deliberado por parte de las autoridades colombianas de retrasar el proceso de concesión hasta que pudiera constituirse legalmente el parque nacional. Así mismo señalan que la creación del parque nacional implicó una confiscación funcional a los derechos inherentes a la concesión minera; a pesar de ello, la ANM continuó aceptando los pagos anuales que se realizan durante la fase de explotación, las fases de montaje y construcción de la operación minera. Otro de los argumentos esbozados por los demandantes se refiere al trámite para la constitución del parque, especialmente en lo relacionado a la consulta previa a las comunidades indígenas, la cual, según estos, se hizo en menos de un mes cuando estas convocatorias tardan más tiempo. De igual forma manifiestan que ni el Incora, ni el Instituto Colombiano de Antropología, ni representantes de localidades municipales fueron involucrados en la consulta previa para la constitución del Parque Nacional Yaigojé-Apaporis.

Por otra parte, en el escrito de demanda se indica que los reclamantes Cosigo Resources Ltd. y Cosigo Resources Sucursal Colombia son parte en el proceso arbitral por tener un interés legítimo en el contrato de concesión que se discute. En cuanto a este aspecto existen inquietudes acerca de la legitimación por activa de estas dos partes, especialmente de Cosigo Resources Ltd., sociedad constituida en Canadá. Debido a que la reclamación se fundamenta en el TLC con Estados Unidos, en principio solo los inversionistas de este país estarían protegidos por este acuerdo. Aun así, según se advierte en la demanda, la justificación para que Cosigo Resources Ltd. sea parte en el proceso arbitral es que Tobie Mining transfirió la mayoría de sus intereses en la reclamación a Cosigo Resources Ltd.; pero posteriormente, en 2015, de un negocio entre Tobie Mining y Cosigo Resources Ltd. se trasladó nuevamente a Tobie Mining los derechos mayoritarios en la reclamación de Taraira Sur.

Debido a la justificación del porqué Cosigo Resources Ltd. también es reclamante, en el aviso de demanda se aclara que esta empresa se reserva el derecho de interponer una demanda de arbitraje bajo las normas del CDUMI de acuerdo con las disposiciones del TLC Colombia-Canadá. Es decir sobre los mismos hechos se podría estar ventilando esta controversia ante dos tribunales arbitrales de inversión diferentes, quienes podrían llegar a decisiones contradictorias ${ }^{90}$, lo cual puede acarrear un mayor costo y gasto administrativo para Colombia.

90 Cruz, M. Cosigo Resources, Tobie Mining y Cosigo Resources Sucursal Colombia notifican formalmente demanda de inversión en Colombia. Bogotá, 18 de abril de 2016; dispo- 
La posición del Estado colombiano ${ }^{91}$, por su parte, se cimenta sobre la base de que en el año 2007, cuando Tobie Mining presentó una propuesta de contrato de concesión minera sobre una zona ubicada en el Taraira Sur, el área solicitada ya se encontraba dentro de la Reserva Forestal de la Amazonía y del Resguardo Indígena Yaigojé, por lo que en el año 2008 la Asociación de Comunidades Indígenas de Yaigojé Apaporis (ACIYA) emprendió el proceso para que el Gobierno declarara su territorio parque nacional. Por otra parte, en la evaluación jurídica de la propuesta para el contrato de concesión minera, Ingeominas manifestó que en el evento en que el contrato de concesión fuese otorgado, este debía solicitar la sustracción del área de la reserva forestal para poder desarrollar cualquier actividad de exploración o explotación minera. Así el parque se haya creado dos días antes de la suscripción del contrato de concesión minera, estos acuerdos sólo producen efectos a partir de su inscripción en el Registro Minero Nacional, y este fue inscrito solo en diciembre de $2009^{[92]}$.

El Mincit en su escrito de respuesta propone que el arbitraje sea llevado a cabo conforme con el Convenio CIADI y su reglamento, e invita a los demandantes a presentar su notificación de arbitraje ante este Centro. El Estado colombiano, en su respuesta a la notificación de arbitraje, rechazó el reclamo formulado por los demandantes y objetó la jurisdicción del tribunal en razón de la materia, de la persona, del tiempo y de la voluntad de las partes ${ }^{93}$. Los argumentos esbozados en la respuesta del Mincit se resumen en los siguientes aspectos: i) las demandantes no han demostrado que lleven a cabo alguna actividad en Colombia que se pueda considerar como una inversión bajo el artículo 10.28 del TLC, así como tampoco han probado la existencia de pérdidas o perjuicio sufridos por el supuesto incumplimiento de Colombia a las obligaciones derivadas del TLC; ii) Cosigo Resources, Ltd. y Cosigo Resources Sucursal Colombia no son inversionistas protegidos por el TLC, y Tobie Mining no ha demostrado ser una persona jurídica constituida en Estados Unidos; de ser así no tendría actividades comerciales sustanciales, por lo que notifica formalmente la denegación de los beneficios del TLC de conformidad con el artículo 10.12.2; iii) debido a que los hechos que sustentan la reclamación son anteriores a la entrada en vigencia del TLC con Estados Unidos, esto es, el 15 de mayo de 2012, el Tribunal no tendría jurisdicción para decidir estos reclamos en virtud del artículo 10.1.3 del TLC; y por último,

nible en: http://dernegocios.uexternado.edu.co/controversia/cosigo-resources-tobie-mining-ycosigo-resources-sucursal-colombia-notifican-formalmente-demanda-de-inversion-a-colombia/ [Consultado el 22 de febrero de 2017].

91 Ibíd.

92 Respuesta de la República de Colombia a la notificación de arbitraje, Ministerio de Comercio, Industria y Turismo; disponible en: http://www.mincit.gov.co/tlc/publicaciones. php?id=35985 [Consultado el 22 de febrero de 2017].

93 Ibíd. 
iv) los demandantes no han cumplido con los requisitos establecidos por el artículo 10.17 del TLC para que la oferta de arbitraje sea efectiva.

Adicionalmente se solicita al tribunal que bifurque el procedimiento para que primero se resuelvan los asuntos relacionados con la jurisdicción del tribunal, antes de atender los asuntos de fondo de la controversia.

\subsubsection{Análisis del caso}

El artículo 10.1 .3 excluye la aplicación del Capítulo Diez de Inversión a cualquier acto, hecho o situación que cesó de existir antes de la fecha de entrada de vigencia del presente acuerdo, que fue en el año 2012. Como se observa, los hechos de la disputa son del año 2009, y atendiendo a lo consagrado en el artículo 28 de la Convención de Viena sobre el derecho de los tratados, los efectos del TLC en relación con el capítulo de inversión no son retroactivos.

En este sentido, se podría concluir, tal como lo señaló el Mincit, que el tribunal podría carecer de jurisdicción ratione temporis. En ATA Construction, Industrial and Trading Company v. Jordania el tribunal aceptó los argumentos del Estado por tratarse de una disputa anterior a la entrada de vigencia del BIT $^{94}$, en los siguientes términos:

En consecuencia, el Tribunal considera que la disputa sobre la anulación de la sentencia definitivo per se (en oposición a la extinción del Acuerdo de Arbitraje) es realmente indistinguible de la disputa original y, por lo tanto, como ésta surgió antes de la entrada en vigencia del твI Turquía-Jordania, en consecuencia, todas las reclamaciones relacionadas con la anulación de la sentencia per se son inadmisibles por falta de jurisdicción ratione temporis.

A su vez, el artículo 10.18.1 del TLC establece que ninguna reclamación podrá someterse a arbitraje de inversión si han transcurrido más de tres años a partir de la fecha en que el demandante tuvo conocimiento de la violación alegada conforme con el artículo 10.16; es evidente que ya expiró el plazo para someter una reclamación a arbitraje en este caso, con fundamento en estas disposiciones.

En relación con el incumplimiento del artículo 10.17 del TLC, respecto del consentimiento de las partes, esta norma requiere que el mismo se dé por medio de un acuerdo escrito ya sea conforme con el Convenio del CIADI y las Reglas del Mecanismo Complementario del CIADI, la Convención de Nueva York o Interamericana. Sin embargo, tribunales arbitrales han desechado la tesis bajo la cual, previo a iniciar un arbitraje de inversión, el inversionista debe otorgar un consentimiento por escrito. En SGS v. Filipinas el tribunal

94 ATA Construction, Industrial and Trading Company v. The Hashemite Kingdom of Jordan, Caso CIADI n. ${ }^{\circ}$ ARB/08/2. Laudo arbitral del 18 de mayo de 2010, pár. 103. 
arbitral señaló que el demandante había aceptado la oferta de consentimiento realizada por Filipinas en el TBI, cuando registró la solicitud de arbitraje, considerando así agotado el requisito de "consentimiento escrito" previsto en la Convención de Washington ${ }^{95}$.

Respecto de la actividad económica desarrollada por el demandante, y de si esta puede ser considerada como inversión; según el TLC con Estados Unidos, los contratos de concesión están comprendidos dentro de este concepto. Ahora bien, será el tribunal el que determinará tal cuestión basándose en un criterio subjetivo u objetivo.

Respecto de la participación de Cosigo Resources, Ltd. y Cosigo Resources Sucursal Colombia como convocantes, el tribunal arbitral tendrá que estudiar si su participación es legítima para ser considerados inversores protegidos por el TLC con Estados Unidos, y delimitar la relación comercial o de cualquier otro tipo que tenga Tobie Mining con Cosigo Resources.

En relación con la expropiatoria sin compensación a la luz de una medida regulatoria, tribunales arbitrales como el de Methanex $v$. USA han manifestado que cuando una regulación de interés público sea no discriminatoria, y la misma respete el debido proceso, a pesar de que afecte a un inversionista extranjero esta por sí misma no se considera expropiatoria y compensable. En Feldam v. México el tribunal señaló:

... los gobiernos deben tener la libertad de actuar en pro del interés público más amplio a través de la protección del medio ambiente, regímenes impositivos nuevos o modificados, el otorgamiento o cancelación de subsidios gubernamentales, la reducción o el aumento de los niveles arancelarios, la imposición de zonas restringidas y medidas similares. Ninguna reglamentación gubernamental razonable de este tipo puede lograrse si se permite que los negocios que se vean perjudicados busquen una indemnización, y cabe afirmar con certeza que el derecho internacional consuetudinario reconoce esta circunstancia ${ }^{96}$.

\section{CONCLUSIONES}

Independientemente de si los AII atraen un mayor flujo de IED, lo cierto es que el ambiente internacional propicia que se suscriban más tratados internacionales de este tipo; aun así, debe prestarse atención a los términos con los que se pactan los mismos para no menoscabar la soberanía nacional.

95 SGS Société Générale de Surveillance S.A. v. Filipinas, Caso CIADI n. ${ }^{\circ}$ ARB $/ 02 / 6$. Decisión sobre jurisdicción del. Otros casos Eudoro Armando Olguín v. República de Paraguay, Caso CIADI n. ${ }^{\circ}$ ARB/98/5; Tradex Hellas S.A. v. Republic of Albania, Caso CIADI n. ${ }^{\circ}$ ARB/94/2; y Sempra Energy International v. República de Argentina, Caso CIADI n. ${ }^{\circ}$ ARB/02/16.

96 Marvin Roy Feldman Karpa v. Estados Unidos Mexicanos, Caso CIADI n. ${ }^{\circ}$ ARB(AF)/99/1. Laudo arbitral del 16 de diciembre de 2012, pár. 103. 
Es muy temprano para entrar a concluir la efectividad de la regulación y los sistemas implementados por el Estado colombiano en relación con la prevención temprana, oportuna y óptima de las controversias internacionales, y si estas tienen en realidad un efecto práctico a la hora de soslayar una arbitraje inversionista-Estado, o si por el contrario quedaron rebosadas al agotamiento de un periodo para acudir a la vía arbitral. La eficiencia de la etapa de consultas y arreglo directo puede fortalecerse mediante una participación más activa de la entidad pública con la que se originó el conflicto, y la intervención de terceros interesados, afectados directamente o indirectamente por las decisiones que se tomen en esta etapa o por la eventual afectación a sus derechos o intereses.

Considerando lo cuantiosas que son este tipo de demandas, es importante implementar efectivamente la Directiva Presidencial de 2016, a efectos de tener una comprensión del alcance de estos acuerdos internacionales y evitar en lo posible cualquier riesgo que pueda generar una reclamación a nivel internacional.

La experiencia ante estos tribunales arbitrales internacionales es necesaria para conocer el ambiente en el que se ventilan estas controversias; así el resultado de los casos sea incierto, su lectura debe realizarse en contraste con casos similares para estar un paso delante de aquellas cuestiones que puedan implicar una responsabilidad. Como lo ha tratado el Estado colombiano, los puntos de choque que deben primero abordarse son los relativos a la jurisdicción, y alegar la falta de esta por parte del panel arbitral, ya sea por aspectos temporales, de la materia o de la persona. El punto capcioso de estas controversias, como en todo proceso litigioso, es el análisis de fondo que realicen los tribunales. Como se observó, en casos similares respecto de una materia de protección puede haber varias perspectivas, que en ciertas ocasiones son favorables a los Estados, y en otras al inversionista extranjero.

Los resultados de estos procesos arbitrales permitirán una retroalimentación y reforzamiento de las estrategias que deben implementarse por parte del Mincit, la Instancia de Alto Nivel de Gobierno, el Grupo de Apoyo interinstitucional y los asesores externos que apoyen la defensa del Estado colombiano. No puede perderse de vista que la guía para llevar a cabo estos procesos arbitrales está dada por el AII respectivo, y muchas veces en estos se puede encontrar aquellos aspectos que pueden beneficiar al Estado receptor.

\section{REFERENCIAS}

Ampuero, A. Trato nacional, trato nación más favorecida, nivel mínimo de trato y expropiación en los Acuerdos Internacionales de Inversión. Disponible en: http://www.oas. org/es/sla/ddi/docs/publicaciones_digital_xxxIV_curso_derecho_internacional_2007_ Ana_A_Ampuero_Miranda.pdf [Consultado el 20 de febrero de 2017]. 
AndRade, X. (2010). Renuncia al arbitraje previsto en un tratado: el caso ecuatoriano. Revista Ecuatoriana de Arbitraje, Instituto Ecuatoriano de Arbitraje. n. . 2, 183-208.

Blackaby, N. (2004). El arbitraje según los tratados bilaterales de inversión y tratados de libre comercio en América Latina. Revista Internacional de arbitraje, Legis. n. ${ }^{\circ} 1$, junio-diciembre de, 17-63.

Bohoslavsky, J. P. Tratados de protección de las inversiones e implicaciones para la formulación de políticas públicas (especial referencia a los servicios de agua potable y saneamiento), Documento de Proyecto n. ${ }^{\circ}$ 326. Comisión Económica para América Latina y el Caribe (CEPAL). Disponible en: http://repositorio.cepal.org/handle/11362/3769 [Consultado el 20 de febrero de 2017].

CÁrdenas, A. Algunas reflexiones sobre la ley aplicable a los arbitrajes de inversión derivados de Acuerdos Internacionales de inversión. Disponible en: http://dernegocios. uexternado.edu.co/D3rn3goc10sEUC/wp-content/uploads/2016/11/2016-11-24-Leyaplicable-en-los-AII.pdf [Consultado el 19 de febrero de 2017].

\section{Convenio ciadi.}

Cruz, M. Cosigo Resources, TobieMining y Cosigo Resources Sucursal Colombia notifican formalmente demanda de inversión en Colombia. Bogotá, 18 de abril de 2016. Disponible en: http://dernegocios.uexternado.edu.co/controversia/cosigo-resources-tobie-miningy-cosigo-resources-sucursal-colombia-notifican-formalmente-demanda-de-inversiona-colombia/ [Consultado el 22 de febrero de 2017].

Dolzer, R. y Schreuer, C. (2008). Principles of International Investment Law. New York: Oxford University Press, , 179.

Endara, F. (2011). Derecho aplicable al fondo de la controversia en arbitrajes surgidos de tratados de inversión. Revista Chilena de ciencia y política. Vol. 3, n. ${ }^{\circ}$ 1, 101-117.

FAYA, A. ¿Cómo se determina una expropiación indirecta bajo tratados internacionales en materia de inversión? Un análisis contemporáneo. Instituto de Investigaciones Jurídicas, Universidad Nacional Autónoma de México. Disponible en https://archivos.juridicas. unam.mx/www/bjv/libros/7/3386/8.pdf [Consultado el 20 de febrero de 2017].

Franck, S. (2007). Foreign Direct Investment, Investment Treaty Arbitration, and the Rule of Law. McGeorge Global Business and Development Journal. Vol. 19, 337-373.

Garavito, A.; Iregui, A. y Ramírez, M. (2012). Inversión extranjera directa en Colombia: evolución reciente y marco normativo. Borradores de Economía, Banco de la República. n. ${ }^{\circ} 713,1-64$.

García, L. y Arévalo, W. (2016). Arbitraje de inversión. Definición y aspectos procesales relevantes. En García, L. y Aluure, A., eds. Estudios contemporáneos de derecho internacional privado. Bogotá: Universidad del Rosario y Legis Editores, , 243-278.

Grabowski, A. (2014). The definition of investment under the ICsid Convention: A defense of Salini. Chicaco Journal of International Law. Vol. 15, n. ${ }^{\circ}$ 1, 287-309.

Gutiérrez, M. (2015). Entre la observancia de los Acuerdos de Protección a la Inversión y el derecho a instrumentar políticas públicas de desarrollo en América Latina. En 
Álvarez, J., ed. ¿Hacia dónde va América Latina en el derecho internacional de las inversiones? Bogotá: Universidad Externado de Colombia.

Heiskanen, V. (2014). Ménage à trois? Jurisdiction, Admissibility and Competence in Investment Treaty Arbitration. ICSCID Review, Oxford Academic. Vol. 29, n. ${ }^{\circ}$ 1, 231-246.

Heiskanen, V. (2010). Of capital import: The definition of "investment" in international law. En Koffmann, A. Protection of Foreign Investments through modern treaty arbitration: Diversity and harmonisation. ASA Special Series n. ${ }^{\circ} 34$. Association Suisse de l'Arbitrage Schweiz, 51-73.

McClure, M. Most favoured nation clauses - No favoured view on how they should be interpreted. Disponible en: http://kluwerarbitrationblog.com/2011/07/25/most-favourednation-clauses-no-favoured-view-on-how-they-should-be-interpreted/ [Consultado el 20 de febrero de 2017].

Monroy, M. C. (2015). La cláusula de la nación más favorecida en los tratados bilaterales de inversión vigentes para Colombia y sus efectos de acuerdo con laudos arbitrales CIADI. Revista de Derecho Público, Universidad de los Andes. n. ${ }^{\circ} 35$, julio-diciembre, 1-34.

Mortimore, M. Arbitraje internacional basado en cláusulas de solución de controversias entre los inversionistas y el estado en acuerdos internacionales de inversión: desafíos para América latina y el Caribe. CEPAL. Serie Desarrollo Productivo. Disponible en: http://repositorio.cepal.org/bitstream/handle/11362/4583/1/S0900332_es.pdf [Consultado el 19 de febrero de 2017].

PÁez, M. (2006). La expropiación indirecta frente al CIADI: consideraciones para la autorregulación de los actos administrativo del Estado. Revista de Estudios Internacionales, Universidad de Chile. Vol. 39, n. ${ }^{\circ}$ 153, abril-junio, 5-36.

Pérez, Y. (2013). Consentimiento estatal al arbitraje del CIADI. Lecciones y ensayos. n. ${ }^{\circ}$ 91, 19-57.

Pérez, Y. (2012). Objeciones a la jurisdicción arbitral de Ciadi. Cuadernos de Derecho Transnacional, Universidad Carlos III de Madrid. Vol. 4, n. ${ }^{\circ}$ 1, 316-333.

Pérez, Y. (2013). Oferta estatal de consentimiento en el procedimiento arbitral CIAdi. Ciencias Sociales y Educación, Universidad de Medellín. Vol. 2, n. 3, 33-64.

Reglamento de Arbitraje y reglas de procedimiento CIADI.

Reglamento de Arbitraje de la CNUDMI.

Reglamento de Arbitraje de la ICC.

Schreuer, C. (2005). Fair and Equitable Treatment in Arbitral Practice. The Journal of World Investment and Trade. Vol. 6, n. ${ }^{\circ}$ 3, 357-386.

Sommer, C. (2014). La aplicación de estándares de protección de inversiones extranjeras. Una mirada desde los casos argentino. ACDI-Anuario Colombiano de Derecho Internacional, Universidad del Rosario. Vol. 6, 95-130.

Torterola, I. (2011). Cláusulas escalonadas en el arbitraje de inversión. En Soto, C. Tratado de derecho arbitral. Colección estudios n. ${ }^{\circ}$ 2. Bogotá: Pontificia Universidad 
Javeriana, Facultad de Ciencias Jurídicas, Grupo Editorial Ibáñez e Instituto Peruano de Arbitraje, 287-295.

United Nations Conference on Trade and Development [UNCTAD] (2008). Regulación internacional de la inversión: Balance, retos y camino a seguir. Nueva York y Ginebra: Naciones Unidas.

United Nations Conference on Trade and Development [UnCTAD] (2000). Taking of property. Nueva York y Ginebra: Naciones Unidas.

\section{Jurisprudencia}

ATA Construction, Industrial and Trading Company v. The Hashemite Kingdom of Jordan, Caso CIADI n. ${ }^{\circ} \mathrm{ARB} / 08 / 2$.

Biwater Gauff (Tanzania) Ltd. v. United Republic of Tanzania, Caso CIADI n. ${ }^{\circ}$ ARB/05/22.

CMS Gas Transmission Company vs. República de Argentina, Caso CIADI n. ${ }^{\circ}$ ARB/01/8.

Corte Constitucional. Sentencia C-035 de 2016.

Corte Constitucional. Sentencia C-555 de 2013.

Crystallex International Corporation v. República Bolivaria de Venezuela, Caso CIADI n. ${ }^{\circ}$ $\operatorname{ARB}(\mathrm{AF}) / 11 / 2$.

El Paso Energy International Co. vs. Argentina, Caso CIADI n. ${ }^{\circ}$ Arb/03/15.

Ethyl Corporation v. The Government of Canada, Caso UnCITRAL.

Glamis Gold, Ltd. v. The United States of America, Caso UnCITRAL.

Gold Reserve Inc. v. Bolivaria de Venezuela, Caso CIADI n. ${ }^{\circ}$ ARB(AF)/09/1.

Khan Resources Inc., Khan Resources B.V., and Cauc Holding Company Ltd. v. The Government of Mongolia, Caso UnCITRAL.

Metalclad Corporation v. Estados Unidos Mexicanos, Caso CIAdi n. ${ }^{\circ}$ ARB (AF)/97/1.

MTd Equity Sdn. Bhd. and mtd Chile S.A. vs. República de Chile, Caso CIADI n. ${ }^{\circ}$ ARb/01/7.

Murphy Exploration and Production Company International vs. República del Ecuador. Caso CIADI n. ${ }^{\circ}$ ARB $/ 08 / 4$.

Plama Consortium Limited v. Republic of Bulgaria, Caso CIADI n. ${ }^{\circ}$ ARB/03/24.

Pope \& Talbot Inc.v. The Government of Canada, Caso UnCitral.

Rusoro Mining Ltd. v. Bolivarian Republic of Venezuela, ICSID Case n. ${ }^{\circ}$ ARB(AF)/12/5.

S.D. Myers, Inc. v. Government of Canada, Caso Uncitral.

Saluka Investments B.V. v. The Czech Republic, Caso UnCitraL. 
Sempra Energy International v. República de Argentina, Caso CIADI n. ${ }^{\circ}$ ARB/02/16.

SGS Société Générale de Surveillance S.A. v. Filipinas, Caso CIADI n. arb/02/6.

Southern Pacific Properties (Middle East) Limited v. Arab Republic of Egypt, Caso CIADI n. ${ }^{\circ} \mathrm{ARB} / 84 /$.

Técnicas Medioambientales Tecmed, S.A. v. Estados Unidos Mexicanos, Caso CIADI n. ${ }^{\circ}$ ARB (AF)/00/2.

Thunderbird Gaming Corporation v. Estados Unidos Mexicanos, Caso UnCITRAL.

Waste Management, Inc. vs. Estados Unidos Mexicanos, Caso CIADI n. ${ }^{\circ}$ ARB/98/2. 